\title{
Geochemistry, mineral chemistry and pressure-temperature conditions of the Jõhvi magnetite quartzites and magnetite-rich gneisses, NE Estonia
}

\author{
Alvar Soesoo $^{\mathrm{a}, \mathrm{b}}$, Siim Nirgi ${ }^{\mathrm{a}, \mathrm{c}}$, Kristjan Urtson $^{\mathrm{b}}$ and Margus Voolma ${ }^{\mathrm{d}}$

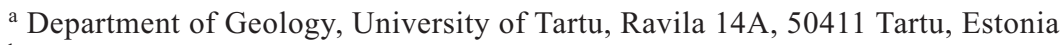 \\ ${ }^{\mathrm{b}}$ Department of Geology, Tallinn University of Technology, Ehitajate tee 5, 19086 Tallinn, Estonia; alvar.soesoo@gmail.com \\ ${ }^{c}$ Geological Survey of Estonia, Kreutzwaldi 5, 44314 Rakvere, Estonia \\ d Merivälja Highschool, Heki tee 16, 12112 Tallinn, Estonia
}

Received 28 July 2020, accepted 5 October 2020, available online 15 March 2021

\begin{abstract}
The Jõhvi magnetite quartzites (MagQ) occur as subvertical beds with a complicated structural outline in biotite-garnetcordierite and pyroxene gneisses which in places also contain high concentrations of iron. Drill core study shows that the complex of MagQ and magnetite-rich gneisses may be up to $100 \mathrm{~m}$ thick. The MagQ provide a wide range of chemical composition: $\mathrm{SiO}_{2}$ ranges between 40.3 and $60.1 \mathrm{wt} \%, \mathrm{Al}_{2} \mathrm{O}_{3}$ between 1.7 and $19.7 \mathrm{wt} \%$ and total iron between 15 and $45.2 \mathrm{wt} \%$. This study also revealed unusually high manganese contents of $1-6 \mathrm{wt} \%$. The rare earth element (REE) patterns of MagQ and the surrounding gneisses partly overlap. Cutting granitoids form two different REE patterns. Magnetite occurs as anhedral grains elongated along rock fabric, as rounded inclusions in other minerals or as tiny platelets along grain edges and along cleavage planes of amphibole and biotite. Sulphides are present as pyrite, pyrrhotite and other minor sulphide minerals (chalcopyrite, galena and sphalerite). Analysis of the magnetite grains from drill core J-1 shows that classifying Jõhvi magnetites into a certain deposit type is not unambiguous.

The garnet-biotite geothermometer revealed metamorphic temperatures between 650 and $750{ }^{\circ} \mathrm{C}$. The garnet-biotite-plagioclasequartz geobarometer yielded the pressure range of 2.9 to $4.9 \mathrm{kbar}$. However, having in mind that the entire Jõhvi ore complex may be a result of repeated metasomatic events, which have influenced the primary volcanic-sedimentary sequences, the estimate of primary pressure-temperature conditions might not be a straightforward task. The current understanding of the geological-geochemical correlation hints at geological similarities between the Bergslagen area in Sweden and the Jõhvi Zone in Estonia.
\end{abstract}

Key words: iron ore, magnetite quartzites, geochemistry, ore minerals, pressure-temperature conditions, Jõhvi Zone, Estonia.

\section{INTRODUCTION}

The crystalline basement of Estonia represents one of the least known parts of the East European Craton (Soesoo et al. 2004, 2006; Bogdanova et al. 2015). It consists of Palaeoproterozoic high-grade metamorphic (amphibolite to granulite facies) and igneous rocks that are covered by 100-700 m of Palaeozoic and Neoproterozoic sedimentary rocks. Accordingly, the available geological information on the crystalline basement in Estonia comes mostly from studies of drill core material and geophysical measurements. During the 1950s-1980s, the Estonian basement rocks were extensively drilled and studied for ore perspective.

From a series of magnetic anomalies established in the Estonian basement the most striking is the Jõhvi mag- netic anomaly discovered already in 1924 (Fig. 1). These anomalies are mainly caused by magnetite-rich rocks (Jõhvi and Sakusaare anomalies) and sulphide-graphitebearing gneisses (Uljaste, Haljala and Assamalla anomalies). The first two drill holes, J-1 (505.03 m) and J-2 $(721.5 \mathrm{~m})$, were drilled into the Jõhvi magnetic anomaly during 1937-1939 by the company 'Magna'. The studies of drill cores revealed a thick iron ore formation whose extent, unfortunately, remained unknown. During the Soviet times, several exploratory drill holes were drilled into the Jõhvi magnetic anomaly. However, most of the research stopped in the late 1980s.

All these Jõhvi drill cores but J-1 and J-2 have been lost due to fire in a drill core shed. On the basis of previous information (now more than 40 years old) it was established that the Jõhvi magnetite quartzites (MagQ) 


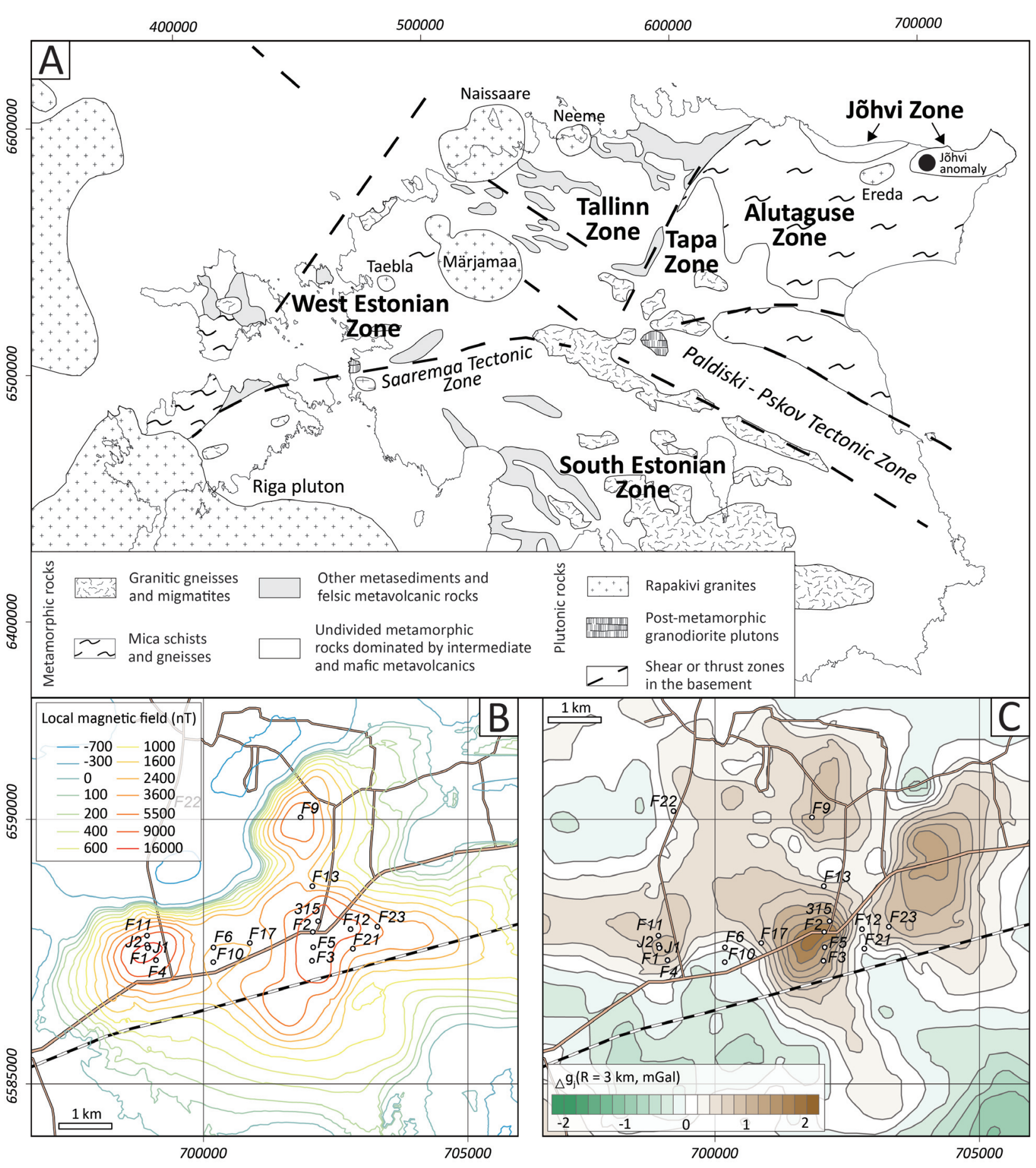

Fig. 1. The main geological outline of the Estonian Precambrian basement and the location of the Jõhvi Zone (A). Magnetic (B) and gravimetric (C) fields of the Jõhvi magnetic anomaly with location of historical drill holes.

occurred as subvertical beds in garnet-cordierite and/or pyroxene gneisses. The surrounding gneisses may in places also contain a high concentration of iron.

Earlier drillings have shown that the complex of magnetite-rich rocks including MagQ and gneisses (iron-rich gneisses) is about $100 \mathrm{~m}$ thick, and the reserves of iron ore $(\mathrm{Fe}$ over $25 \%$ ) are about 355 million tonnes if calculated to a depth of $500 \mathrm{~m}, 629$ million tonnes if calculated to a depth of $700 \mathrm{~m}$ and 1500 million tonnes if calculated to a depth of $1000 \mathrm{~m}$ (Soesoo et al. 2004). 
These estimates, however, are based on very limited data and need to be assessed by drilling in the future. During the last 30 years, no geological work has been conducted in the area, albeit the interest of international mining companies in exploration at Jõhvi has been high for decades. Although iron may yet not be of the highest economic interest, the sulphide mineralization-related base metals ( $\mathrm{Zn}, \mathrm{Pb}, \mathrm{Cu}, \mathrm{Ag}$ and others) are needed on the market and may thus be important for the Estonian economics in the future.

As the Jõhvi geological zone bears several geochemical differences from the rest of the Estonian crystalline basement, the geology of the area has been revisited. During late 2019-early 2020, two new inclined holes were drilled in the vicinity of drill hole $\mathrm{J}-1$, unfortunately, the new material is not available yet. The main focus of this paper is to provide data on general geochemistry, mineral chemistry, ore microscopy and assess possible pressure-temperature $(P-T)$ conditions of the Jõhvi iron ore formation.

\section{GEOLOGICAL OVERVIEW OF THE ESTONIAN BASEMENT ROCKS AND THE POSITION OF THE JÕHVI ZONE}

The Estonian Precambrian basement can be considered as a southern continuation of the Fennoscandian Shield rock complexes of the East European Craton. This basement comprises two major units: amphibolite facies rocks of northern Estonia, which are similar to the rocks of southern Finland and mostly granulite facies rocks of southern Estonia.

Based on geophysical and petrological studies, six structural-geological zones can be distinguished within these major units: the Tallinn, Alutaguse and Jõhvi zones, located in northern Estonia and the West Estonian, Tapa and South Estonian zones (Fig. 1; Puura et al. 1983; Soesoo et al. 2004, 2020). The rocks with granulite metamorphic assemblages are found in several zones within the Estonian Precambrian basement. In the South Estonian and Jõhvi zones, the granulite facies mineral assemblages are still preserved, while in the Tapa and West Estonian zones the rocks were mostly retrogressed under amphibolite facies conditions (Fig. 1).

The Tallinn Zone is characterized by negative freeair gravity and magnetic fields. The zone is bordered by a regional deformation zone in the southwest, which separates it from the West Estonian Zone (Fig. 1). Another, less prominent tectonic zone separates the Tallinn Zone from the Tapa Zone in the east. The rocks of the Tallinn Zone vary from mafic amphibolite facies metavolcanites to metasediments represented by amphibole gneisses, biotite-plagioclase gneisses, quartz-feldspar gneisses, mica gneisses, and minor sulphide-graphite gneisses and MagQ.

The Alutaguse Zone is characterized by near-zero free-air gravity and slightly negative magnetic anomalies. Local positive anomalies are possibly associated with sulphide-graphite gneisses (black schists), quartzites, skarn carbonaceous rocks and pyroxene gneisses. The main rock types of the Alutaguse Zone are alumina-rich gneisses (with biotite, cordierite, garnet, sillimanite) and biotite-plagioclase gneisses, less abundant are amphibole gneisses, amphibolites and quartz-feldspar gneisses. The rocks of the Alutaguse Zone have metamorphosed under the conditions of amphibolite facies.

The Tapa Zone is bordered by tectonic contacts from the Tallinn Zone in the west and the Alutaguse Zone in the east, while the southern contact with the West Estonian Zone is not so clearly defined (Fig. 1). The zone is characterized by slightly positive gravity and frizzy magnetic anomalies. The main rock types comprise a sequence of alternating $\mathrm{Fe}$ - and Si-rich garnet-pyroxene-bearing quartzites, high-Al garnet-cordierite-sillimanite gneisses, and $\mathrm{Ca}$-rich and $\mathrm{Ca}$-poor pyroxene, amphibole and biotite gneisses. Mineralogical assemblages indicate amphibolite and granulite facies metamorphism.

The West Estonian Zone is bounded by the NWtrending tectonic zone and the E-W-striking Middle Estonian Saaremaa tectonic zone. The zone is dominated by metasedimentary rocks in the amphibolite to granulite facies, resembling somewhat the rocks in the southern part of the Bergslagen area in Sweden (Bogdanova et al. 2015). The main rock types in the West Estonian Zone are medium- to fine-grained amphibolites, biotite-plagioclase gneisses, and quartz-feldspar gneisses with minor pyroxene gneisses. The mineral assemblage of these rocks points to the high-temperature amphibolite facies and in many places to the granulite facies metamorphism (Puura et al. 1983, 2004; Soesoo et al. 2020).

The South Estonian Zone (Fig. 1) comprises predominantly meta-igneous rocks and minor meta-sedimentary rocks. This zone is characterized by a band of intensive gravity and magnetic anomalies embracing the southern part of Estonia and northern Latvia. The magnetic field is strongly differentiated, the anomalies are generally linear and trend $\mathrm{E}-\mathrm{W}$ or $\mathrm{N}-\mathrm{S}$. The gravity field anomalies are coarsely mosaic. The boundary between the South and West Estonian zones generally follows the tectonic zones. The South Estonian Zone contains both mafic and felsic granulitic components - amphibolepyroxene and biotite-hypersthene gneisses, and quartzfeldspar gneisses.

The Jõhvi Zone is a narrow 20-30 km wide and $100 \mathrm{~km}$ long zone complex in NE Estonia, separated from the South Estonian Zone by the Alutaguse Zone amphibolite 
grade gneisses (Fig. 1). The zone is characterized by extremely strong (up to $19300 \mathrm{nT}$ in the Jõhvi magnetic anomaly) E-W-trending magnetic anomalies and slight positive gravity anomalies (Plado et al. 2020). The complex consists of pyroxene gneisses, quartz-feldspar gneisses, biotite-plagioclase gneisses, amphibole gneisses, garnet-cordierite gneisses (Vaivara complex) and MagQ (the cause of the Jõhvi magnetic anomaly). Migmatization is widespread, resulting in the formation of leucosomes and small granitoid veins and bodies with charnockitic and enderbitic compositions (Soesoo et al. 2006, 2020). Generally, these rocks have formed under the conditions of granulite facies metamorphism. Some of the rocks of this zone may have high ore potential.

The Jõhvi MagQ occur as subvertical beds with complicated internal structures in garnet-cordierite or pyroxene gneisses. Seven out of historically drilled 17 drill holes in the area of the Jõhvi magnetic anomaly contain magnetite-rich gneisses. Historical, as well as the present study, shows that the complex of MagQ may be up to $100 \mathrm{~m}$ thick. Due to complicated structural features (probably several folding epochs) and unorientated drill cores the real thickness of the ore zone needs to be established during future drillings and research. The section of drill core J-1 is shown in Fig. 2 as an example of the Jõhvi iron formation.

\section{MATERIAL AND METHODS}

The descriptions of major rock types in the drill cores of the study area are based on about 500 thin sections and 11 hand specimens that had been selected and prepared as a part of the crystalline bedrock mapping during 1960-1980 (Erisalu et al. 1969; Puura et al. 1983). The present study includes samples from the following drill cores:

F-1 (N59 22,766'; E27 30,220');

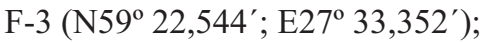

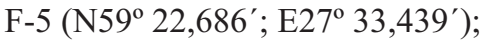

F-9 (N59 23,996'; E27 33,286');

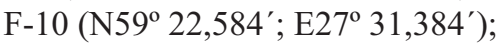

F-11 (N59 $\left.22,888^{\prime} ; \mathrm{E} 27^{\circ} 30,090^{\prime}\right)$;

F-12 (N59 $\left.22,849^{\prime} ; \mathrm{E} 27^{\circ} 34,281^{\prime}\right)$;

F-13 (N59 $\left.23,306^{\prime} ; \mathrm{E} 27^{\circ} 33,465^{\prime}\right)$;

F-21 (N59 $\left.22,645^{\prime} ; \mathrm{E} 27^{\circ} 34,180^{\prime}\right)$;

F-23 (N59 $\left.24,147^{\prime} ; \mathrm{E} 27^{\circ} 34,692^{\prime}\right)$;

$\mathrm{J}-1$ (N59 $\left.{ }^{\circ} 22,776^{\prime} ; \mathrm{E} 27^{\circ} 30,142\right)$;

$\mathrm{J}-2\left(\mathrm{~N}^{\circ} 9^{\circ} 22,806^{\prime} ; \mathrm{E} 27^{\circ} 30,126^{\prime}\right)$;

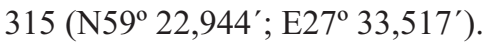

The bulk composition of the Jõhvi MagQ, surrounding iron-rich gneisses and other gneisses, and granitoid rocks was analysed in the 11 selected samples of archived hand specimens at the Department of Geology, Tallinn

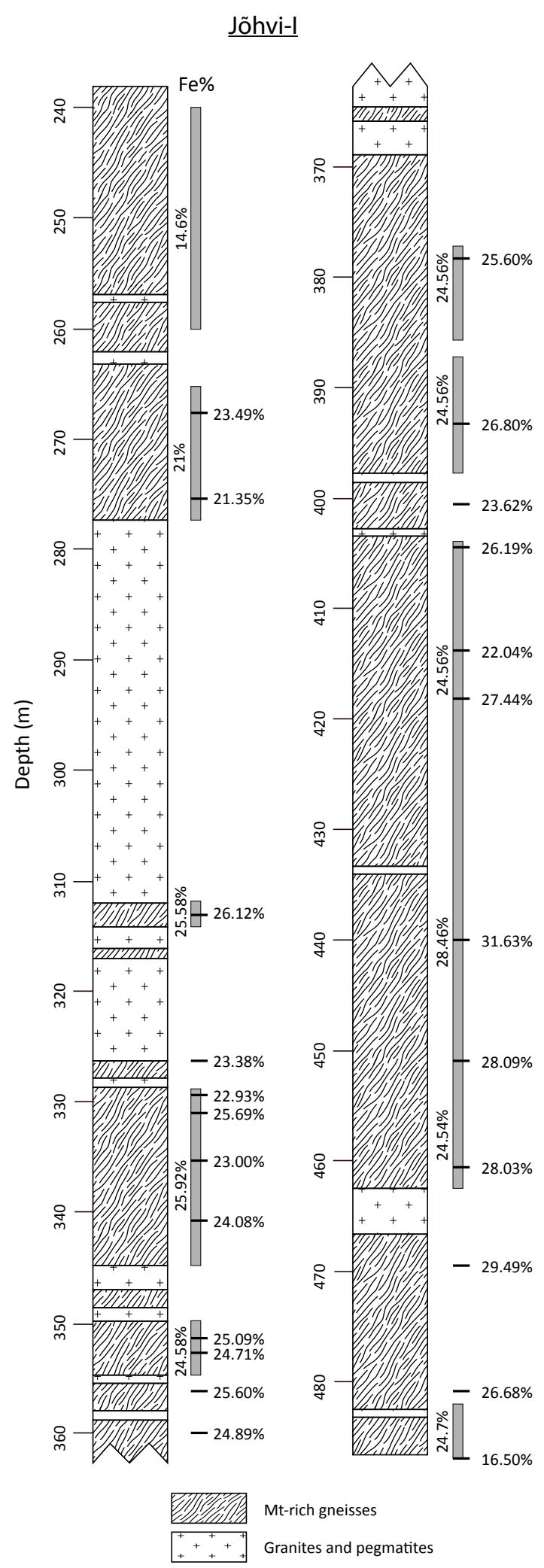

Fig. 2. Simplified cross section of drill core J-1 of the Jõhvi area. The cross section is based on the original logging in 1940 (Report No. 8, https://fond.egt.ee/fond/egf/8). Average iron contents $(\mathrm{Fe} \%)$ are shown for ore sections (vertical values) and for sites of the present analyses (horizontal values). 
University of Technology, using the Bruker S8 XRF spectrometer on lithium metaborate fused glass disks and Thermo X-series II quadrupole ICPMS on liquid samples prepared by lithium metaborate fusion and subsequent dissolution in dilute nitric acid. The ICPMS instrument at Tallinn University of Technology was calibrated using multi-element standard solutions from Inorganic Ventures. For quality control, GeoPT certified proficiency testing materials GRI-1 (granite) and TLM-1 (tonalite) were used (www.geoanalyst.org/geopt).The two preserved drill cores (J-1 and J-2) out of 17 that were drilled in the area of the magnetic anomaly were reviewed and sampled. Bulk chemical composition was analysed in 56 samples of various rock types in Bureau Veritas Minerals, Canada, using four-acid digestion or lithium borate fusion together with inductively coupled plasma mass spectrometry (ICP-MS) and inductively coupled plasma emission spectroscopy (ICP-ES).

Ore microscopy studies were carried out at the Department of Geology, Tallinn University of Technology on selected 40 polished thick sections from drill cores $\mathrm{J}-1, \mathrm{~J}-2,315, \mathrm{~F}-1, \mathrm{~F}-13, \mathrm{~F}-5$ and F-9, sampled and prepared in the 1960s during the crystalline bedrock mapping. The sections were re-polished and examined using reflected light microscopy in plane-polarized and cross-polarized incident light. As polished thin sections were not available for the particular samples, the study was focused on reflective ore minerals only.

Mineral chemistry was studied on samples from drill cores J-1, J-2, F-1 and F-12 using a scanning electron microscope with energy dispersive and wavelength dispersive spectrometry and laser ablation coupled ICP-MS methods at the University of Tartu and Tallinn University of Technology in order to

(1) establish compositional spectra of rock-forming minerals;

(2) investigate rock unit formation conditions;

(3) compare the magnetite trace element fingerprint with other magnetite-ore deposit types.

Altogether, 38 analysis from 5 magnetite grains were performed from the polished section of MagQ in drill core $\mathrm{J}-1$ (312.1 $\mathrm{m}$ ) by laser ablation inductively coupled plasma mass spectrometry (LA-ICP-MS) using Agilent 8800 quadrupole ICP-MS coupled to a Cetac LSX 213 G2+ laser at the University of Tartu. The GSE-2G certified reference material was used as an external calibration standard, and BCR-2G was used as a quality control standard.

Pressure-temperature conditions that reflect the metamorphism environment at the time of equilibration were described from a set of selected samples.

The distribution of $\mathrm{Fe}^{2+}$ and $\mathrm{Mg}$ was analysed in coexisting phases controlled by the following exchange reactions between garnet-biotite (a) and garnetclinopyroxene (b) end members: (a) $\mathrm{Fe}_{3} \mathrm{Al}_{2} \mathrm{Si}_{3} \mathrm{O}_{12}+\mathrm{KMg}_{3} \mathrm{AlSi}_{3} \mathrm{O}_{10}(\mathrm{OH})_{2}=\mathrm{Mg}_{3} \mathrm{Al}_{2} \mathrm{Si}_{3} \mathrm{O}_{12}+$ $\mathrm{KFe}_{3} \mathrm{AlSi}_{3} \mathrm{O}_{10}(\mathrm{OH})_{2}$ Almandine $(\mathrm{Grt})+$ Phlogopite $(\mathrm{Bt})=$ Pyrope $(\mathrm{Grt})+$ Annite (Bt)

(b) $1 / 3 \mathrm{Mg}_{3} \mathrm{Al}_{2} \mathrm{Si}_{3} \mathrm{O}_{11}+\mathrm{CaFeSi}_{2} \mathrm{O}_{6}=1 / 3 \mathrm{Fe}_{3} \mathrm{Al}_{2} \mathrm{Si}_{3} \mathrm{O}_{12}+$ $\mathrm{CaMgSi}_{2} \mathrm{O}_{6}$

Pyrope $(\operatorname{Prp})+$ Hedenbergite $(\mathrm{Hd})=$ Almandine $(\mathrm{Alm})+$ Diopside (Di)

\section{ROCK DESCRIPTIONS}

The studied samples can be divided into three major rock groups: (1) gneisses and iron-rich gneisses, (2) MagQ and (3) granitoids. Gneisses, iron-rich gneisses and MagQ can be divided according to the content of primary and accessory (low-content) minerals and magnetite into garnet-pyroxene-amphibole gneisses, pyroxene-garnet, amphibole-garnet-feldspar-pyroxene, iron-rich gneisses and MagQ. The mineralogical composition of gneisses is quite variable, spanning from heavily migmatized biotite gneisses to garnet-cordierite-andalusite gneisses. The content of iron-rich minerals, primarily magnetite, is also quite variable in both MagQ and magnetite-rich surrounding gneisses.

\section{Biotite gneisses}

Biotite gneisses occur as rather thin layers alternating with other types of gneisses including MagQ. Gradual transitions between biotite gneisses and other types of gneisses can be seen. In some places, the gneisses are also migmatized. The mineralogical composition of biotite gneisses varies highly, with an approximate composition of quartz (20-50\%), plagioclase $(20-50 \%)$, potassium feldspar $(10-30 \%)$, biotite $(10-40 \%)$ and garnet $(0-5 \%)$. However, amphibole, sillimanite, cordierite, apatite, zircon and magnetite may also occur. Sericite, chlorite and epidote represent secondary minerals. The protolith of the biotite gneisses can be considered of volcanic-sedimentary origin (Puura et al. 1983).

\section{Biotite-pyroxene-amphibole gneisses}

Several different gneisses with the amphibole and pyroxene content over $5 \%$ can be classified under this group. With regard to different mineral composition of gneisses, various names of gneisses referring to the most common mineral can be used. The gneisses are mostly medium-grained and in places weakly migmatized. The mineral composition varies highly with an approximate ratio of pyroxene $(5-20 \%)$, amphibole $(5-40 \%)$, biotite $(10-20 \%)$, plagioclase $(20-60 \%)$, quartz $(10-30 \%)$ and 
potassium feldspar (0-25\%). Apatite, zircon, magnetite and pyrite can also be found.

\section{Aluminium-rich gneisses}

Aluminium-rich gneisses are widely spread in the drill cores. They are alternating with other types of gneisses and have often smooth transitional boundaries. Granitic veins cutting all types of gneisses can also be seen. Aluminium-rich gneisses have varying mineral composition with plagioclase $(0-40 \%)$, potassium feldspar $(0-35 \%)$, quartz $(0-50 \%)$, garnet $(0-40 \%)$, biotite $(0-40 \%)$, sillimanite $(0-20 \%)$ and cordierite $(0-40 \%)$. Some graphite, andalusite and muscovite but also apatite, monazite, zircon, pyrite and magnetite may be present. According to their characteristics, aluminium-rich gneisses can be classified as paragneisses with a clayey and sandy type of sedimentary precursor with some volcanic addition (Puura et al. 1983).

\section{Magnetite quartzites}

Magnetite quartzites are found in seven drill cores. According to present knowledge, MagQ occur in the epicentres of magnetic anomalies. These gneisses are commonly very fine-grained, in most cases manganiferous rocks with thin foliated beds/layers where quartz is alternating with dark minerals (Fig. 3). Rocks from drill core F-12 are more massive. Main minerals in MagQ are quartz $(10-75 \%)$, magnetite $(10-50 \%)$, plagioclase
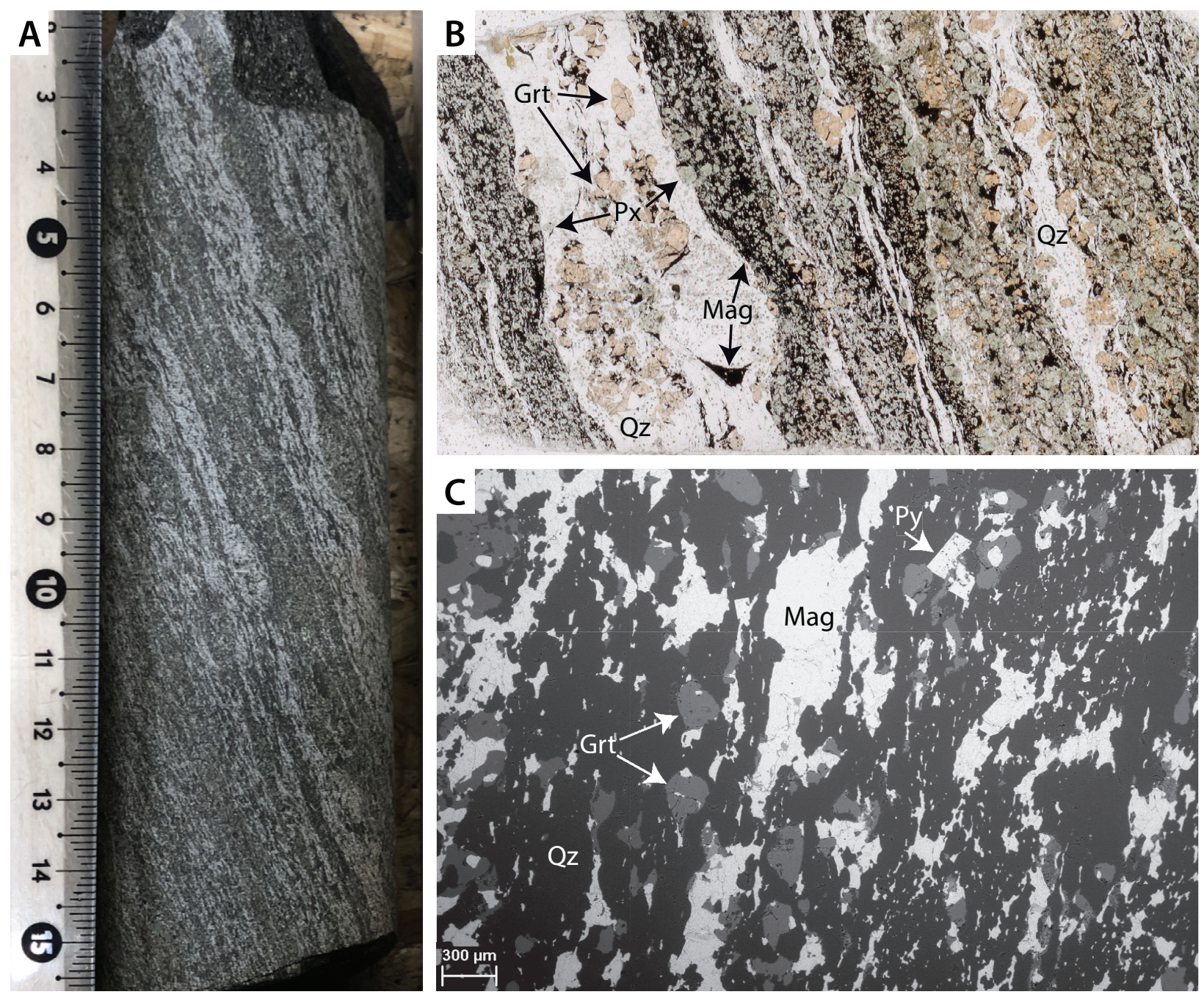

Fig. 3. A, an example of drill core with banded texture typical of magnetite quartzites in the Jõhvi iron formation, drill core Jõhvi PA-2, depth 482.65-482.8 m. Photomicrographs of quartz layers alternating with interlayers of dark minerals in foliated magnetite quartzites (B, plane-polarized light, drill core F1, depth $347.3 \mathrm{~m}$; C, scanning electron microscope, drill core Jõhvi PA-1, depth 511.0 m). Qz, quartz; Grt, garnet; Px, pyroxene; Mag, magnetite; Py, pyrite. 
(0-35\%), potassium feldspar $(0-10 \%)$, clinopyroxene $(0-20 \%)$, orthopyroxene $(0-20 \%)$, garnets $(0-20 \%)$, pyrite $(1-2 \%)$ and pyrrhotite $(1-2 \%)$. Also, apatite and zircon can be found. Plagioclase is mainly represented as andesine, rarely as anorthite. Quartz occurs in different grain sizes, often acting as matrix filling gaps between other mineral grains. Few bipyramidal quartz crystals are present, but mostly quartz forms mosaic masses and layers between dark minerals. Magnetite is disseminated randomly between other minerals and in places forms pressure shadows aside porphyroblasts of garnet and feldspar. Garnets are of $0.1-0.3 \mathrm{~mm}$ size, anhedral, sometimes elongated and contain inclusions of magnetite, zircon, quartz, galena and monazite. In places garnet grains can be larger than $1 \mathrm{~cm}$. The main accessory minerals are zircon, monazite, apatite, titanite, ilmenite, pyrite, sphalerite, chalcopyrite, hematite and allanite.

\section{Granitic gneisses}

Gneissic rocks with nearly granitic composition can be considered monotonous in their structure and texture throughout the profile. They are mostly medium-grained, with slight orientation and commonly strongly cataclastic. The mineral composition of granitic gneisses consists of plagioclase $(20-50 \%)$, potassium feldspar $(10-40 \%)$, quartz (10-35\%), biotite (0-15\%), amphibole (0-15\%) and sometimes hypersthene $(0-3 \%)$. Also, apatite, zircon, magnetite, monazite, pyrite and pyrrhotite can be found. Most of the granite gneisses could be defined as paragneisses formed during the metamorphism of primary sedimentary protolith. However, some of the gneisses may also be considered as orthogneisses according to their origin (volcanic protolith; Puura et al. 1983).

\section{Granites, pegmatites and migmatites}

The gneisses are cut by medium- to large-grained granite veins in all drill cores, however, pegmatitic veins and large granitic and pegmatitic bodies (several tens of metres in size) are also common. The granites and pegmatites are microcline and plagio-microcline in their mineral composition. Plagioclase is often replaced by microcline, which may suggest potassium metasomatism. Migmatization is observed in all drill cores. Migmatized and nonmigmatized sections can be easily distinguished visually.

\section{ORE MINERAL DESCRIPTIONS}

The key optical features specific to ore minerals in reflected light are reflectivity (brightness), apparent colour, bireflection (change in reflectivity and apparent colour on rotation in plane-polarized light), anisotropy (change in the apparent colour on rotation in crosspolarized light) and internal reflections of (semi)transparent ore minerals (Craig \& Vaughan 1994). In the Jõhvi samples, optically isotropic magnetite occurs as anhedral grains elongated along rock fabric, interstitially filling the space between other minerals by forming patches of up to several millimetres in size or embedded in silicate minerals as rounded inclusions with the size of $20-100 \mu \mathrm{m}$ (Fig. 4A). Magnetite can also be present as tiny platelets along grain edges and along cleavage planes of amphibole and biotite. The patches of magnetite are often oriented as distinct bands alternating with silicate minerals dominated layers. In some sections magnetite is altered into anisotropic and bireflective hematite along grain edges, cracks and cleavage planes (Fig. 4B). In places, hematite also appears as colloform filling of $5 \mathrm{~mm}$ wide veins cutting subparallel the main rock fabric and cogenetic intensive alteration of magnetite in close proximity to the veins (Fig. 4C, D), suggesting the precipitation from metamorphic fluids or brines.

Sulphides are present mostly as isotropic pyrite, which is occasionally exhibiting weak anisotropy. At some levels anisotropic pyrrhotite occurs, being far less abundant than pyrite. Pyrite appears as sub- to euhedral crystals or interstitial patches between other grains, commonly closely related to magnetite and garnet. Together with magnetite they form ore mineral-rich bands, which are often more pronounced in close proximity to or at the contact with subparallel quartz or granitic veins. At the vein tips, brittle fracturing has occurred with pyrite and magnetite filling the space (Fig. 4E). Sulphides also appear as fillings in later thin veins cross-cutting the main banding (Fig. 4F). Occasional chalcopyrite, galena and sphalerite grains were found in magnetite-rich drill core sections of F-1 and F-5.

Different generations of iron oxides appearing as magnetite or hematite, magnetite to hematite alteration, sulphide precipitation or alteration as a pyrite/pyrrhotite association and minor chalcopyrite, galena and sphalerite, as well as coprecipitation of sulphides and magnetite indicate a complex redox history (e.g. Hall 1986; Lagoeiro 2004; Slotznick et al. 2018) of iron-rich rocks of the Jõhvi area. The succession of general geological processes in time and their relations to specific ore-forming processes are not yet clear and need definitely future studies.

\section{CHEMICAL COMPOSITION OF THE JÕHVI ROCK TYPES}

\section{Major element composition}

The results show that the magnetite quartzites provide a wide range of major element compositions (Table 1; Fig. 5; 

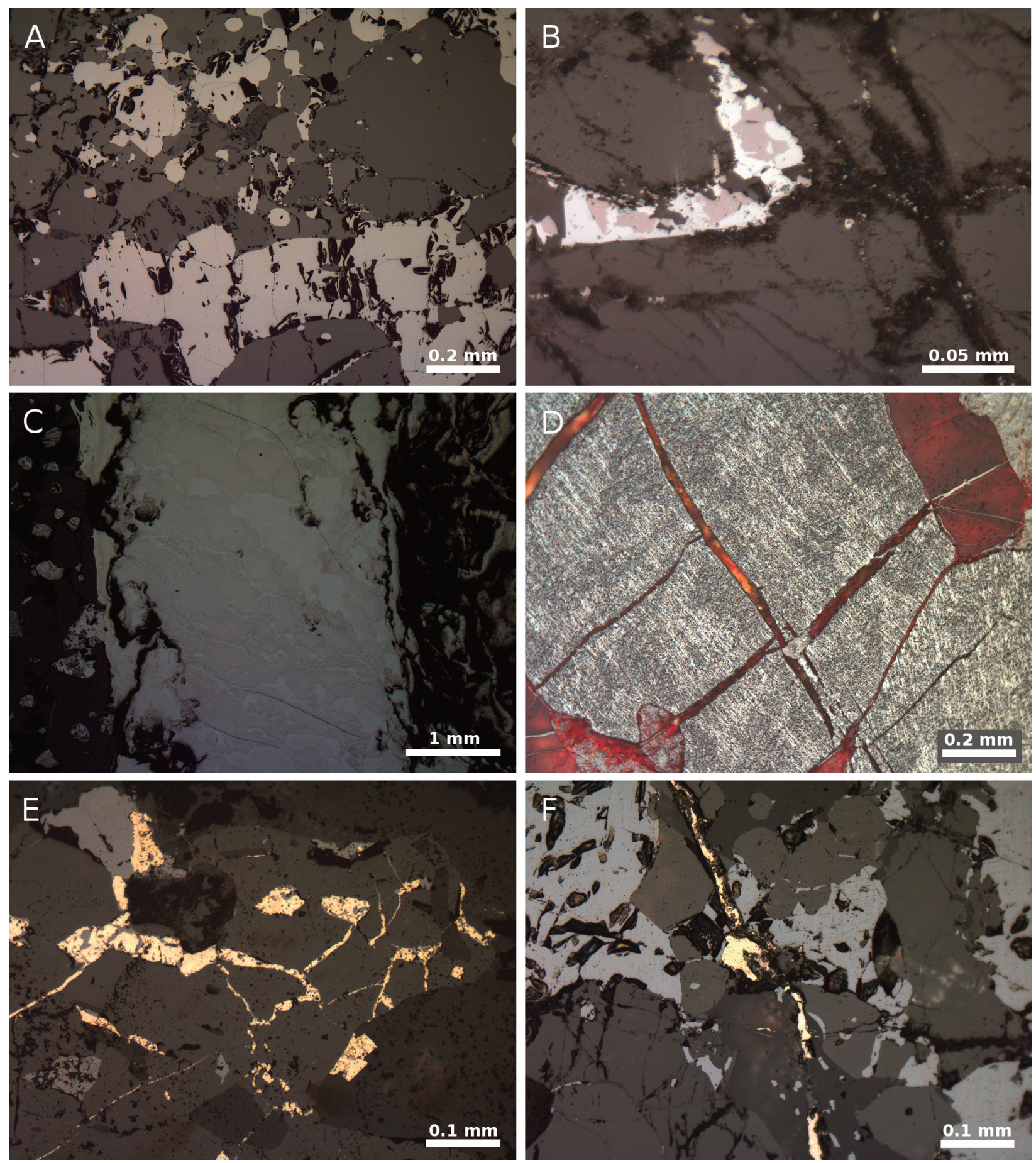

Fig. 4. A, anhedral and elongated magnetite grains (light grey) and rounded inclusions of magnetite embedded in silicate minerals (dark grey). Plane-polarized light. Drill core F-1, depth $317.0 \mathrm{~m}$. B, subhedral magnetite grain (pinkish-grey) partly altered into hematite (white) along edges, cracks and cleavage planes. Plane-polarized light. Drill core 315, depth $298.0 \mathrm{~m}$. C, a subparallel hematite vein with colloform internal structure (light grey, centre), colloform earthy hematite layering (dark, right) and altered subhedral magnetite grains (medium grey, left). Plane-polarized light. Drill core F-9, depth $255.8 \mathrm{~m}$. D, a magnetite grain showing alteration into anisotropic hematite (light grey) as thin lamellae or dust-size spots. Cross-polarized light. Drill core F-9, depth $255.8 \mathrm{~m}$. E, magnetite (light grey) and pyrite (yellow) filling brittle fractures at granitic vein tip (dark grey, lower right). Plane polarized light. Drill core J-1, depth $444.4 \mathrm{~m}$. F, pyrite (yellow) appears as late fracture filling cross-cutting magnetite-rich (light grey) gneiss layering. Plane-polarized light. Drill core J-2, depth $710.0 \mathrm{~m}$. 

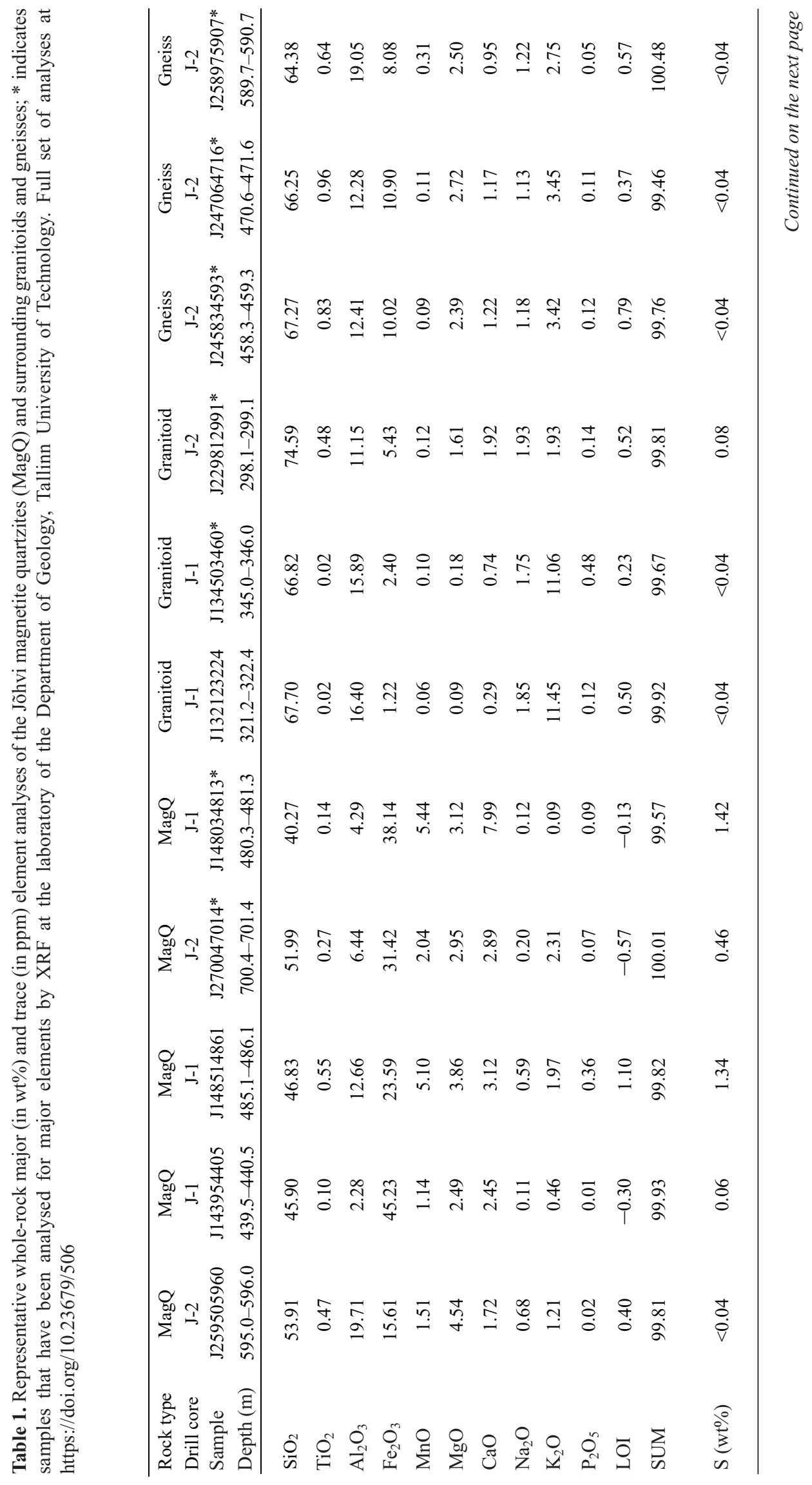


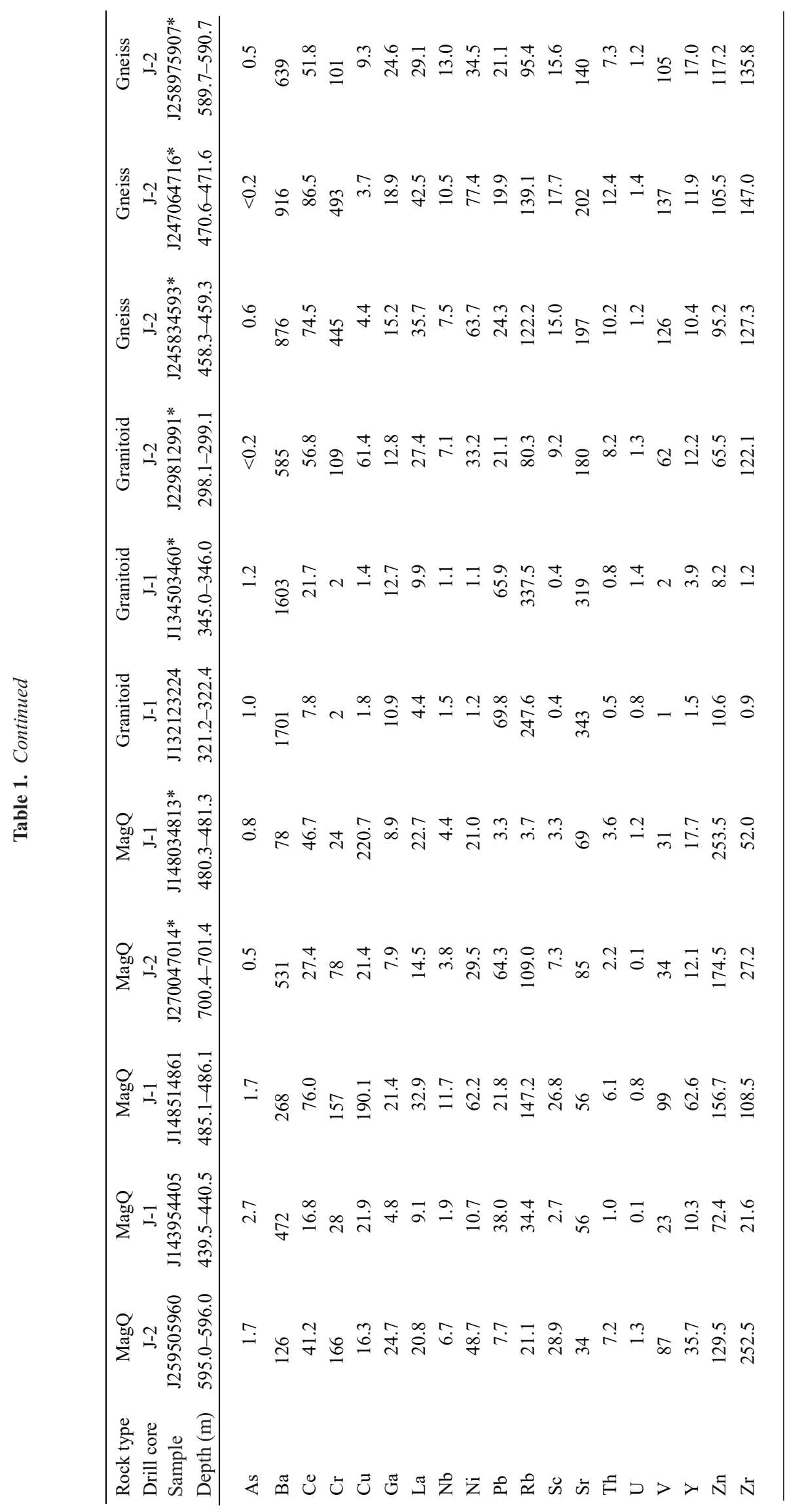



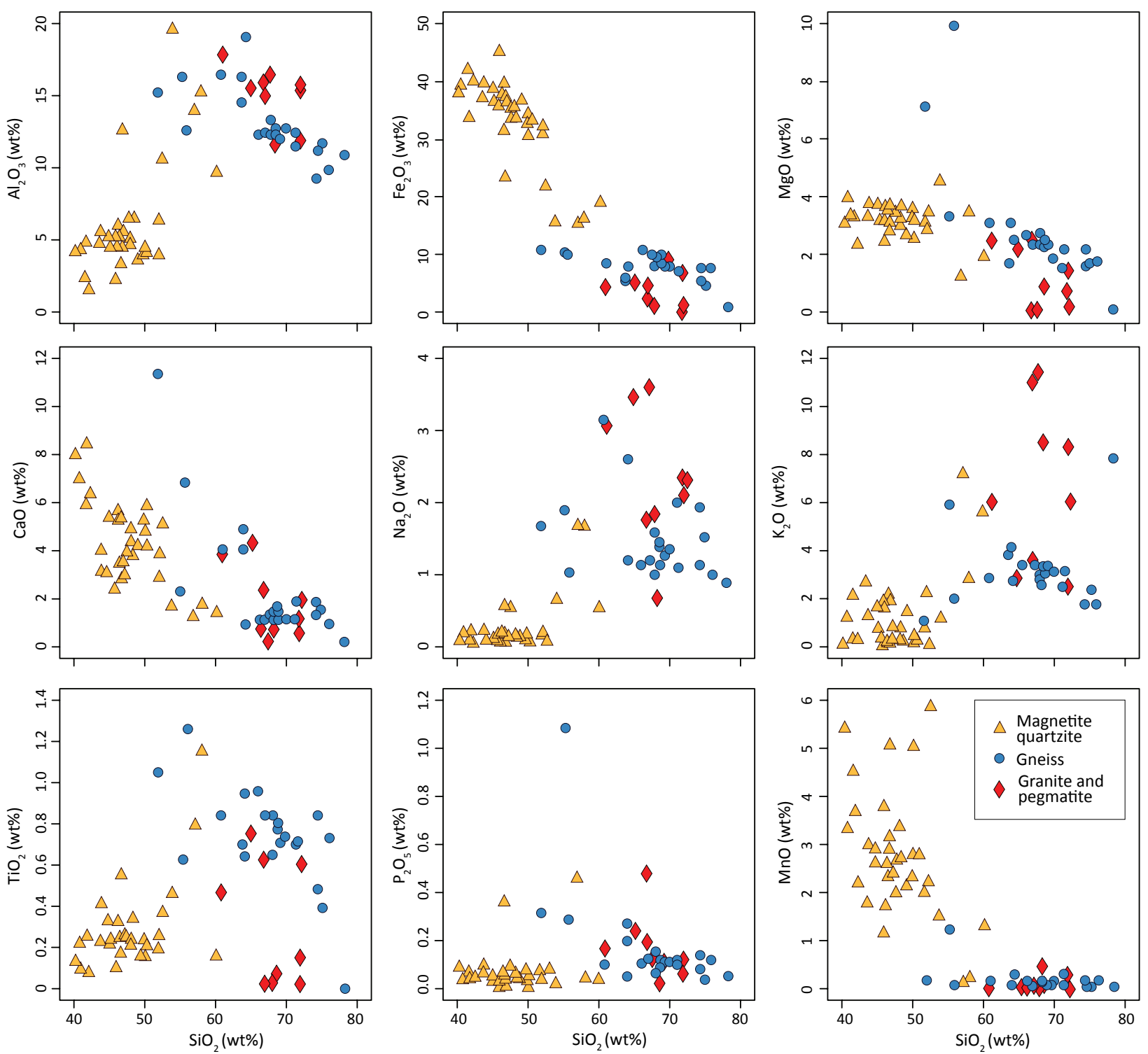

Fig. 5. Geochemical variation plot for selected major oxides in the Jõhvi Zone rock types (in wt\%). Selected geochemical analyses in Table 1; full set of analyses at https://doi.org/10.23679/506.

major and trace element geochemistry of all analysed samples is available in supplementary online data at https://doi.org/10.23679/506). The content of $\mathrm{SiO}_{2}$ ranges from 40.3 to $60.1 \mathrm{wt} \%, \mathrm{Al}_{2} \mathrm{O}_{3}$ from 1.7 to $19.7 \mathrm{wt} \%$ and $\mathrm{Fe}_{2} \mathrm{O}_{3}$ from 15 to $45.2 \mathrm{wt} \%$ (geochemically, MagQ are in this study defined arbitrarily as rock types containing more than $15 \mathrm{wt} \% \mathrm{Fe}_{2} \mathrm{O}_{3}$; the gneisses containing 10-15 wt $\%$ $\mathrm{Fe}_{2} \mathrm{O}_{3}$ can be considered as iron-rich gneisses). The $\mathrm{MgO}$ content varies between 1.30 and $4.54 \mathrm{wt} \%, \mathrm{CaO}$ between 1.3 and $8.5 \mathrm{wt} \%$, and $\mathrm{Na}_{2} \mathrm{O}$ and $\mathrm{K}_{2} \mathrm{O}$ contents can be as high as 1.71 and $7.22 \mathrm{wt} \%$, respectively. The amount of $\mathrm{TiO}_{2}$ ranges from 0.09 to $1.16 \mathrm{wt} \%, \mathrm{P}_{2} \mathrm{O}_{5}$ can be as high as $0.46 \mathrm{wt} \%$ and manganese content is $0.17-5.88 \mathrm{wt} \%$.
In other gneisses that surround the $\mathrm{MagQ}, \mathrm{SiO}_{2}$ ranges from 52 to $76 \mathrm{wt} \%, \mathrm{Al}_{2} \mathrm{O}_{3}$ from 9.3 to $19.1 \mathrm{wt} \%, \mathrm{Fe}_{2} \mathrm{O}_{3}$ from 4.7 to $15 \mathrm{wt} \%$ and $\mathrm{MgO}$ from 1.52 to $9.95 \mathrm{wt} \%$. The $\mathrm{Na}_{2} \mathrm{O}$ and $\mathrm{K}_{2} \mathrm{O}$ contents have slightly higher variance than in MagQ, ranging from 1 to $3.14 \mathrm{wt} \%$ and from 1.06 to $5.93 \mathrm{wt} \%$ respectively. The $\mathrm{TiO}_{2}$ content varies between 0.40 and $1.26 \mathrm{wt} \% ; \mathrm{P}_{2} \mathrm{O}_{5}$ is up to $1.09 \mathrm{wt} \%$ and has also a positive correlation with $\mathrm{CaO}$ that ranges up to $11.4 \mathrm{wt} \%$. Contrary to the high content of $\mathrm{MnO}$ in MagQ, the surrounding gneisses contain less than $1.23 \mathrm{wt} \% \mathrm{MnO}$.

In granitic and pegmatitic rocks the content of $\mathrm{SiO}_{2}$ ranges from 61 to $72 \mathrm{wt} \%, \mathrm{Al}_{2} \mathrm{O}_{3}$ from 11.62 to $17.92 \mathrm{wt} \%$, $\mathrm{Fe}_{2} \mathrm{O}_{3}$ from 0.3 to $8.3 \mathrm{wt} \%, \mathrm{MgO}$ from 0.09 to $2.58 \mathrm{wt} \%$ 
and $\mathrm{CaO}$ from 0.29 to $4.34 \mathrm{wt} \%$. The $\mathrm{Na}_{2} \mathrm{O}$ and $\mathrm{K}_{2} \mathrm{O}$ values can be as high as 3.63 and $11.45 \mathrm{wt} \%$, respectively. The $\mathrm{TiO}_{2}$ content is between 0.02 and $0.76 \mathrm{wt} \%$, $\mathrm{P}_{2} \mathrm{O}_{5}$ ranges from 0.02 to $0.48 \mathrm{wt} \%$ and $\mathrm{MnO}$ is below $0.46 \mathrm{wt} \%$.

\section{Trace element composition}

Binary diagrams for trace elements and $\mathrm{SiO}_{2}$ compositional behaviour of MagQ, other gneisses and granitoid rocks are presented in Table 1 and Fig. 6 (geochemistry of all analysed samples is available online at https://doi.org/10.23679/506). The cobalt content of MagQ is in most cases higher than in the surrounding gneisses and granites, ranging from 17 to $68 \mathrm{ppm}$. The majority of analysis showed that the Mo content in the rocks was at the background level. About half of the analysed MagQ revealed values up to $23 \mathrm{ppm}$ of Mo with one exception up to $46 \mathrm{ppm}$. The contents of $\mathrm{V}$ range from 88 to 280 $\mathrm{ppm}$ in $\mathrm{MaQ}$, from 2 to $52 \mathrm{ppm}$ in the surrounding gneisses and from 61 to $87 \mathrm{ppm}$ in granitoid rocks. Though, the average content of $\mathrm{V}$ is higher in the surrounding gneisses. While the $\mathrm{Cu}$ content in most of the samples is below $50 \mathrm{ppm}$, MagQ can have $\mathrm{Cu}$ concentrations up to $221 \mathrm{ppm}$. A notably higher difference is seen for the $\mathrm{Zn}$ content that ranges from 61 to $237 \mathrm{ppm}$ in
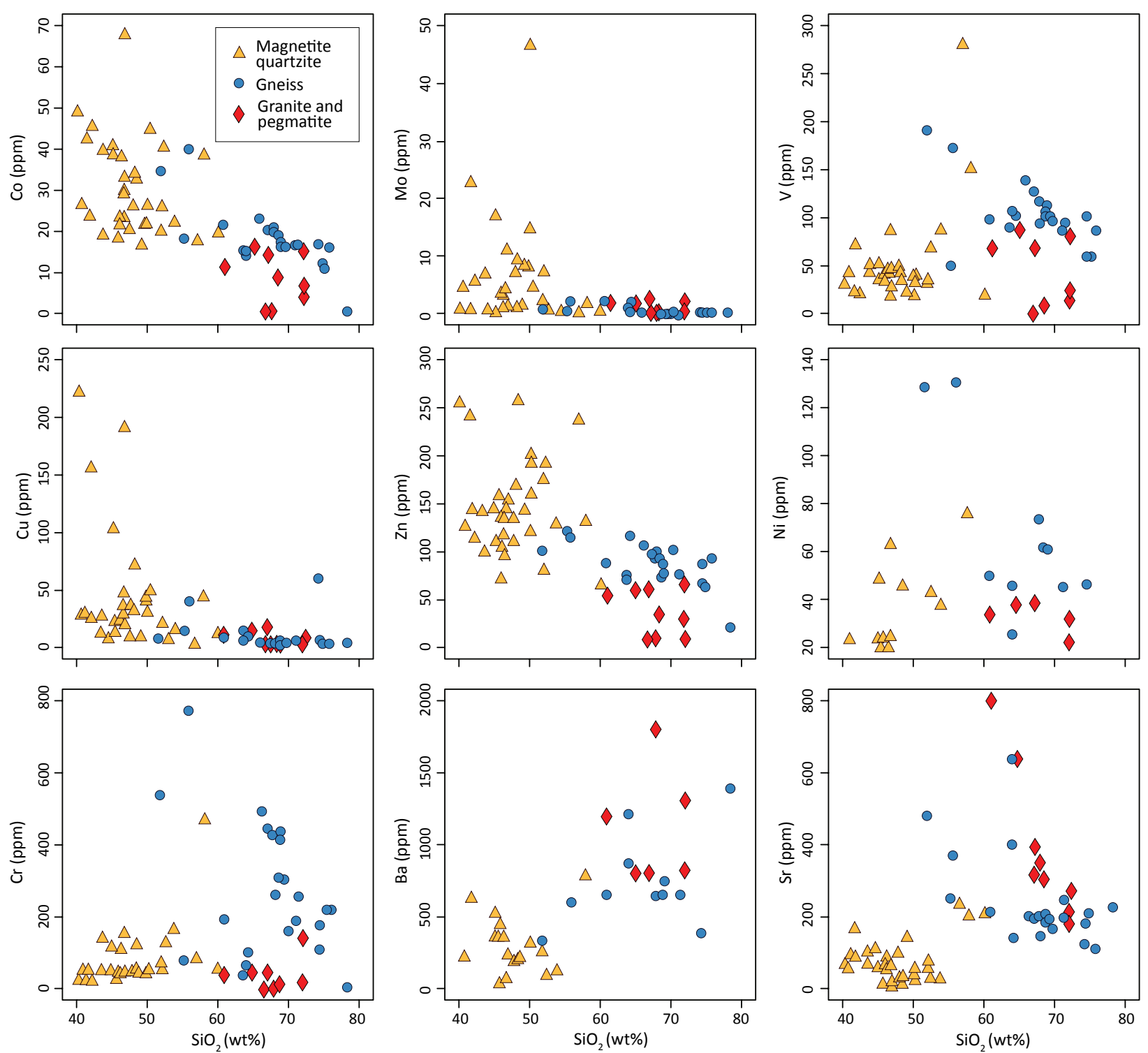

Fig. 6. Geochemical variation plot for selected trace elements in the Jõhvi Zone rock types (in ppm). Selected geochemical analyses in Table 1; full set of analyses at https://doi.org/10.23679/506. 
MagQ, from 8 to $261 \mathrm{ppm}$ in the surrounding gneisses and from 57 to $145 \mathrm{ppm}$ in granitoid rocks. The Ni content was under the detection limit $(<20 \mathrm{ppm})$ in 38 samples. It mostly remained under $77 \mathrm{ppm}$ except for two samples of gneisses with values up to $131 \mathrm{ppm}$. The $\mathrm{Cr}$ content of MagQ was quite undifferentiated and did not exceed $157 \mathrm{ppm}$ with one exception of $470 \mathrm{ppm}$. In the surrounding gneisses, a high variance from 46 to $775 \mathrm{ppm}$ of $\mathrm{Cr}$ content could be seen. A similar trend is observed for $\mathrm{Ba}$ and $\mathrm{Sr}$ contents which in the MagQ are rather undifferentiated, respectively up to 794 and $233 \mathrm{ppm}$, but vary in granitoids respectively from 803 to $1803 \mathrm{ppm}$ and from 190 to $798 \mathrm{ppm}$, and in gneisses from 344 to $1221 \mathrm{ppm}$ and from 114 to $636 \mathrm{ppm}$. It is interesting to note that most of the granitoid rocks show similar trace element contents to the surrounding gneisses (low-iron gneisses; Fig. 6)

\section{Rare earth element composition}

The concentrations of rare earth elements (REE) were obtained from ICP-ES/MS analysis and plotted on the chondrite-normalized (Anders \& Grevesse 1989) spider diagram (Table 2; Fig. 7; geochemistry of all analysed samples is available online at https://doi.org/10.23679/506). Despite a few exceptions, the majority of the MagQ follow a similar pattern to the surrounding gneisses, but have somewhat lower REE, especially of light REE contents. Few high REE values obtained from the surrounding

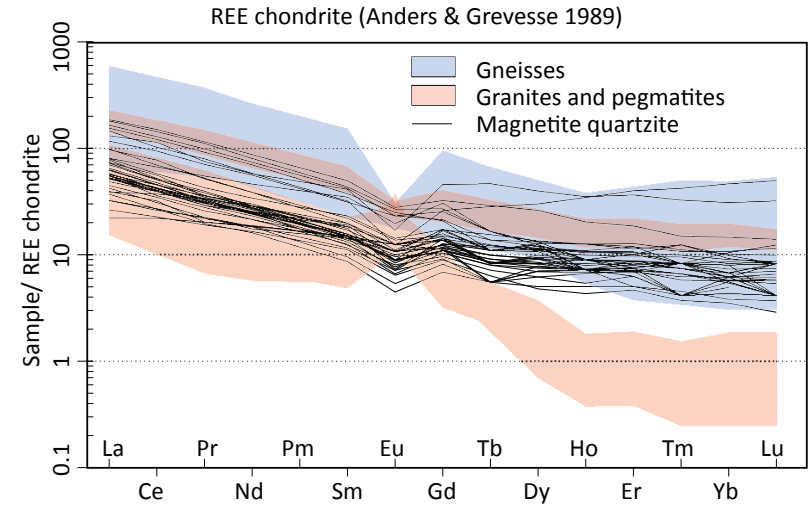

Fig. 7. Chondrite-normalized REE elements in the Jõhvi Zone rock types. Note the overlapping of magnetite quartzites and surrounding gneisses and possibly two geochemical groups for cutting granitoid rocks. Selected geochemical analyses in Table 2; full set of analyses at https://doi.org/10.23679/506.

gneisses, which result in the wide band of the REE pattern, were produced by samples collected near the contact zones of gneisses and granitoids. This gives a reason to believe that fluids passing the rock have been mobilizing a notable amount of at least REE, but probably other trace elements as well.

Granitic and pegmatitic rocks form two different patterns on the REE element chondrite-normalized plot. One of the patterns is similar to the MagQ and also sur-

Table 2. Selected ICP-MS rare earth element analyses in the Jõhvi magnetite quartzites (MagQ) and surrounding granitoids and gneisses. Full set of analyses at https://doi.org/10.23679/506

\begin{tabular}{|c|c|c|c|c|c|c|c|c|}
\hline Rock & MagQ & MagQ & MagQ & Gneiss & Gneiss & Granitoid & Granitoid & Granitoid \\
\hline Drill core & $\mathrm{J}-2$ & $\mathrm{~J}-1$ & $\mathrm{~J}-1$ & $\mathrm{~J}-2$ & $\mathrm{~J}-2$ & $\mathrm{~J}-2$ & J-1 & F-10 \\
\hline Sample & $\mathrm{J} 259505960$ & $\mathrm{~J} 132843294$ & J131193129 & $\mathrm{J} 236583668$ & $\mathrm{~J} 25772$ & $\mathrm{~J} 231783188$ & J132123224 & 10023 \\
\hline Depth (m) & $595.0-596.0$ & $328.4-329.4$ & $311.9-312.9$ & $365.8-366.8$ & 577.2 & $317.8-318.8$ & $321.2-322.4$ & 260 \\
\hline $\mathrm{La}$ & 34.20 & 13.00 & 12.40 & 37.30 & 138.00 & 33.70 & 4.40 & 53.29 \\
\hline $\mathrm{Ce}$ & 61.60 & 21.70 & 24.40 & 74.90 & 275.62 & 69.65 & 7.90 & 111.20 \\
\hline $\operatorname{Pr}$ & 7.10 & 2.48 & 2.76 & 8.18 & 32.80 & 7.70 & 0.86 & 13.16 \\
\hline $\mathrm{Nd}$ & 26.30 & 9.70 & 11.00 & 30.60 & 118.10 & 29.50 & 3.20 & 50.48 \\
\hline $\mathrm{Sm}$ & 4.71 & 1.85 & 2.24 & 5.41 & 22.40 & 6.10 & 0.72 & 9.87 \\
\hline $\mathrm{Eu}$ & 0.69 & 0.37 & 0.47 & 1.01 & 1.70 & 1.30 & 0.65 & 1.79 \\
\hline Gd & 5.11 & 2.04 & 2.47 & 4.76 & 18.60 & 4.00 & 0.63 & 7.91 \\
\hline $\mathrm{Tb}$ & 1.03 & 0.29 & 0.43 & 0.66 & 2.40 & 0.60 & 0.08 & 0.00 \\
\hline Dy & 7.28 & 1.68 & 2.78 & 3.34 & 11.90 & 3.50 & 0.37 & 6.54 \\
\hline Но & 1.92 & 0.38 & 0.58 & 0.60 & 2.10 & 0.80 & 0.05 & 1.21 \\
\hline $\mathrm{Er}$ & 6.34 & 1.09 & 1.66 & 1.66 & 6.90 & 2.80 & 0.10 & 3.49 \\
\hline $\mathrm{Tm}$ & 1.02 & 0.15 & 0.24 & 0.22 & 1.20 & 0.40 & 0.01 & 0.47 \\
\hline $\mathrm{Yb}$ & 7.52 & 1.00 & 1.46 & 1.32 & 7.90 & 2.80 & 0.09 & 3.18 \\
\hline $\mathrm{Lu}$ & 1.21 & 0.14 & 0.21 & 0.21 & 1.30 & 0.40 & 0.01 & 0.42 \\
\hline
\end{tabular}


rounding gneisses (e.g. Eu negative anomaly, comparable light REE/heavy REE ratio), while the other shows depletion of heavy REE and a positive Eu anomaly unlike the other rock types analysed. Hence, the granitoid material could originate from multiple periods and possibly have different sources.

\section{MINERAL CHEMISTRY}

\section{Biotite}

Biotite occurs in a greater variety of geological environments than any of other micas. In metamorphic rocks it is formed under a wide range of $P-T$ conditions, and it occurs abundantly in many contact and regionally metamorphosed sediments. The most common occurrence of biotites and phlogopites is by the metamorphism of pelites, basic and ultrabasic rocks and siliceous limestones and dolomites. Biotite in MagQ is commonly Fe-rich. The $\mathrm{X}_{\mathrm{Mg}}\left(\mathrm{Mg} / \mathrm{Fe}+\mathrm{Mg}+\mathrm{Ti}+\mathrm{Al}^{\mathrm{VI}}\right)$ is 0.46 to 0.55 (Table 3). In sample F12910 the $\mathrm{X}_{\mathrm{Mg}}$ is the lowest, 0.35 as in garnets from the same sample.

\section{Pyroxene}

The studied pyroxenes are mostly clinopyroxenes that belong to the solid solution series between diopside and hedenbergite (or johannsenite). Minerals have approximately equal amounts of manganese and iron; those with a composition closer to johannsenite than hedenbergite are described as ferroan johannsenite, those closer to hedenbergite as manganoan hedenbergite. Diopside and hedenbergite are typical minerals of many metamorphic rocks, being particularly characteristic of contactmetamorphosed calcium/iron-rich sediments (Deer et al. 1992). There are also orthopyroxenes present. Unfortunately only few were analysed, which were compositionally enstatites $-\mathrm{En}_{66} \mathrm{Fs}_{30} \mathrm{Wo}_{4}$ (Table 4).

\section{Garnet}

Garnets in drill core F-12 are Almandine ${ }_{0.6-0.74}$ Pyrope $_{0.20-0.26}$ Grossular $_{0.04-0.07}$ Spessartine $_{0.03-0.1}$. The variations in composition from core to rim are small. The $\mathrm{X}_{\mathrm{Mg}}$ $(\mathrm{Mg} / \mathrm{Fe}+\mathrm{Mn}+\mathrm{Mg}+\mathrm{Ca})$ is $0.20-0.25$ with the lowest value 0.11 in sample F12910 (Table 5).

Table 3. Electron microprobe analyses of biotite of the Jõhvi magnetite quartzites; bdl, below detection limit; nc, not calculated

\begin{tabular}{|c|c|c|c|c|c|c|}
\hline Drill core & F-12 & F-12 & F-1 & F-12 & $\mathrm{J}-1$ & $\mathrm{~J}-2$ \\
\hline Sample & F122517 & F122547 & F12910 & F123276 & J132843294 & $\mathrm{J} 259505960$ \\
\hline Depth (m) & 251.7 & 254.7 & 291 & 327.6 & 328.9 & 595.5 \\
\hline $\mathrm{SiO}_{2}$ & 37.74 & 38.72 & 41.39 & 43.63 & 36.32 & 38.05 \\
\hline $\mathrm{TiO}_{2}$ & 2.91 & 3.04 & 2.34 & 3.39 & 0.97 & 3.10 \\
\hline $\mathrm{Al}_{2} \mathrm{O}_{3}$ & 16.66 & 17.25 & 18.14 & 15.48 & 13.11 & 19.22 \\
\hline $\mathrm{FeO}$ & 17.96 & 19.64 & 19.03 & 15.86 & 15.25 & 16.10 \\
\hline $\mathrm{MnO}$ & bdl & bdl & bdl & 0.00 & 0.76 & 0.07 \\
\hline $\mathrm{MgO}$ & 15.35 & 12.73 & 8.92 & 12.21 & 15.62 & 13.56 \\
\hline $\mathrm{Na}_{2} \mathrm{O}$ & bdl & bdl & 1.04 & 0.46 & 0.18 & bdl \\
\hline $\mathrm{K}_{2} \mathrm{O}$ & 9.07 & 8.61 & 9.14 & 8.96 & 8.91 & 9.75 \\
\hline TOTAL & 99.69 & 100.00 & 100.00 & 100.00 & 90.98 & 99.86 \\
\hline Oxygens & 22 & 22 & 22 & 22 & 22 & 22 \\
\hline $\mathrm{Si}$ & 5.427 & 5.553 & 5.897 & 6.099 & 5.716 & 5.411 \\
\hline $\mathrm{Al}^{\mathrm{iv}}$ & 2.573 & 2.447 & 2.103 & 1.901 & 2.284 & 2.589 \\
\hline $\mathrm{Ti}$ & 0.314 & 0.328 & 0.250 & 0.357 & 0.114 & 0.332 \\
\hline $\mathrm{Al}$ & 0.251 & 0.470 & 0.944 & 0.651 & 0.147 & 0.633 \\
\hline $\mathrm{Fe} 2+$ & 2.160 & 2.355 & 2.267 & 1.854 & 2.007 & 1.915 \\
\hline $\mathrm{Mn}$ & $\mathrm{nc}$ & $\mathrm{nc}$ & $\mathrm{nc}$ & 0.000 & 0.102 & 0.008 \\
\hline $\mathrm{Mg}$ & 3.290 & 2.720 & 1.894 & 2.545 & 3.663 & 2.874 \\
\hline $\mathrm{Na}$ & $\mathrm{nc}$ & $\mathrm{nc}$ & 0.287 & 0.124 & 0.055 & $\mathrm{nc}$ \\
\hline K & 1.664 & 1.576 & 1.662 & 1.598 & 1.788 & 1.769 \\
\hline SUM & 15.679 & 15.449 & 15.304 & 15.129 & 15.876 & 15.531 \\
\hline
\end{tabular}


Table 4. Electron microprobe analyses of pyroxene of the Jõhvi magnetite quartzites. Total iron as $\mathrm{FeO}$, cation formula based on $6 \mathrm{O}$, $\mathrm{En}=\mathrm{Mg} /(\mathrm{Mg}+\mathrm{Ca}+\mathrm{Fe}+\mathrm{Mn}) ; \mathrm{Wo}=\mathrm{Ca} /(\mathrm{Mg}+\mathrm{Ca}+\mathrm{Fe}+\mathrm{Mn}) ;$ $\mathrm{Fs}=\mathrm{Fe} /(\mathrm{Mg}+\mathrm{Ca}+\mathrm{Fe}+\mathrm{Mn}) ;$ nc, not calculated

\begin{tabular}{|c|c|c|c|}
\hline Drill core & F-1 & F-1 & F-1 \\
\hline Sample & F13792 & F13473 & F13473 \\
\hline Depth (m) & 379.2 & 347.3 & 347.3 \\
\hline $\mathrm{SiO}_{2}$ & 50.49 & 48.94 & 56.21 \\
\hline $\mathrm{Al}_{2} \mathrm{O}_{3}$ & 0.55 & 0.00 & 0.27 \\
\hline $\mathrm{FeO}$ & 14.62 & 12.87 & 16.30 \\
\hline $\mathrm{MnO}$ & 6.83 & 28.67 & 5.60 \\
\hline $\mathrm{MgO}$ & 6.85 & 3.52 & 19.99 \\
\hline $\mathrm{CaO}$ & 20.64 & 5.99 & 1.63 \\
\hline TOTAL & 99.99 & 100.00 & 100.00 \\
\hline Oxygens & 6 & 6 & 6 \\
\hline $\mathrm{Si}$ & 1.9892 & 2.0308 & 2.0712 \\
\hline$A l^{i v}$ & 0.0150 & $\mathrm{nc}$ & $\mathrm{nc}$ \\
\hline $\mathrm{Al}$ & 0.0151 & 0.0000 & 0.0116 \\
\hline $\mathrm{Fe}$ & 0.4816 & 0.4467 & 0.5035 \\
\hline $\mathrm{Mn}$ & 0.2281 & 1.0078 & 0.1755 \\
\hline $\mathrm{Mg}$ & 0.4020 & 0.2176 & 1.0963 \\
\hline $\mathrm{Ca}$ & 0.8715 & 0.2662 & 0.0648 \\
\hline SUM & 3.9980 & 3.9692 & 3.9230 \\
\hline Wo & 50 & 29 & 4 \\
\hline En & 23 & 23 & 66 \\
\hline Fs & 27 & 48 & 30 \\
\hline
\end{tabular}

Two types of garnets occur in drill core F-1. One is similar to drill core F-12 $\mathrm{Alm}_{0.62} \operatorname{Prp}_{0.11}$ Gross $_{0.05} \operatorname{Spess}_{0.23}$, but slightly richer in manganese and poorer in magnesium. Other garnets are $\mathrm{Alm}_{0.27-0.34} \operatorname{Prp}_{0.02} \mathrm{Gross}_{0.20-0.28} \operatorname{Spess}_{0.40-0.46}$.

Garnets, in which spessartine is the dominant molecule, are usually found in some skarn deposits. They frequently occur in manganese-rich assemblages with rhodonite, pyroxmangite, tephroite, etc. of metasomatic origin associated either with adjacent igneous intrusions or with a more widespread regional metamorphism (Deer et al. 1992).

Garnet forms solid solutions of spessartine $\mathrm{Mn}_{3} \mathrm{Al}_{2}$ $\left(\mathrm{SiO}_{4}\right)_{3}$, almandine $\mathrm{Fe}_{3} \mathrm{Al}_{2}\left(\mathrm{SiO}_{4}\right)_{3}$, grossular $\mathrm{Ca}_{3} \mathrm{Al}_{2}$ $\left(\mathrm{SiO}_{4}\right)_{3}$, pyrope $\mathrm{Mg}_{3} \mathrm{Al}_{2}\left(\mathrm{SiO}_{4}\right)_{3}$, andradite $\mathrm{Ca}_{3} \mathrm{Fe}_{2}\left(\mathrm{SiO}_{4}\right)_{3}$ (Table 5).

In the studied samples, three distinctly different garnet solid solutions can be distinguished by microprobe mineral chemistry, possibly indicating different protolith: 1. Spess $48.1-50.5 \mathrm{Alm}_{20.1-22.3} \mathrm{And}_{18.6-21.7} \mathrm{Gross}_{0.8-11.1} \operatorname{Prp}_{2.1-4.6}$ occur in the mineral assemblage of garnet-pyroxenemagnetite-quartzite (samples F13792, F13473). Spessartine is rather less common than many of the garnet species. Although the spessartine molecule is present in significant amounts in almandine from granites and rhyolites and from metamorphic rocks, it is rarely dominant in such environments. Garnets in which spessartine is the dominant molecule are found in some skarn deposits. Andradite occurs typically in contact of thermally metamorphosed impure calcareous rocks and particularly in the metasomatic skarn deposits often associated with such metamorphism. This involves the introduction of $\mathrm{Fe}_{2} \mathrm{O}_{3}\left( \pm \mathrm{SiO}_{2}\right)$. If $\mathrm{FeO}$ is also introduced, hedenbergite may form in addition to andradite, while if insufficient silica is present, magnetite may form, giving the typical andradite-hedenbergite-magnetite skarn assemblage.

2. Alm $_{60.3-72.4} \operatorname{Prp}_{19.6-25.3}$ Spess $_{3.6-7.6}$ Gross $_{0.9-4.3} \operatorname{And}_{1.2-3.1}$ occur in the mineral assemblage of garnet-pyroxene-magnetitequartzite (samples F122547, F122517, F123276).

3. $\mathrm{Alm}_{34.3-34.8} \operatorname{Spess}_{33.7-35.5} \operatorname{Prp}_{13.0-13.9}$ Gross $_{9.8-11.1}$ And $_{5.8-7.4}$ occur in the mineral assemblage of garnet-pyroxenemagnetite-quartzite (samples F122788, F123369).

\section{Magnetite}

According to 60 thin sections of gneisses from drill core $\mathrm{J}-1$, the MagQ may contain up to $45 \mathrm{vol} \%$ magnetite. The average magnetite abundance is around $20 \mathrm{vol} \%$.

Large, up to $1 \mathrm{~mm}$, stretched, highly irregular and oriented grains form magnetite-rich bands of different width. Also, abundant rounded and disseminated magnetite grains 5-100 $\mu \mathrm{m}$ in size occur as inclusions in the other rock-forming minerals. Such variance in grain properties refers to the possibility of multiple generations of magnetite. Multi-generation of magnetite is also supported by ore microscopy studies (see above). Trace element concentrations analysed in different magnetite grains show notable variation for several elements (Table 6). This suggests either the impurity of analysed grains or the origin of multiple generations.

\section{Ilmenite}

Ilmenite has been found in the earlier study (unpublished data by M. Voolma and A. Soesoo, 2010-2013) in samples $\mathrm{F} 122788, \mathrm{~F} 123369, \mathrm{~F} 13090$ and F122547. It forms $\left(\mathrm{FeTiO}_{3}\right)$-pyrophanite $\left(\mathrm{MnTiO}_{3}\right)$ solid solution. Ilmenite from samples F122788 and F123369 contains about 30 $35 \mathrm{wt} \% \mathrm{MnO}, 40-45 \mathrm{wt} \% \mathrm{TiO}_{2}$ and $10-20 \mathrm{wt} \% \mathrm{FeO}$ and in sample F13090 about 5-6 wt\% MnO. In ilmenite and magnetite coexisting in igneous and metamorphic rocks, $\mathrm{Mn}$ is always preferentially found in the ilmenite (Deer et al. 1992). Manganoan ilmenite is found in granitic rocks and also in some carbonatites. In solid solution between ilmenite and pyrophanite molecule $\left(\mathrm{MnTiO}_{3}\right)$ the pyrophanite molecule may become important in ilmenites 
Table 5. Electron microprobe analyses of garnet of the Jõhvi magnetite quartzites; bdl, below detection limit; nc, not calculated

\begin{tabular}{|c|c|c|c|c|c|c|c|c|}
\hline Drill core & F-12 & F-12 & F-12 & F-1 & F-1 & F-1 & $\mathrm{J}-1$ & $\mathrm{~J}-1$ \\
\hline Sample & F122517 & F122547 & F123276 & F12910 & F13792 & F13473 & $\mathrm{J} 132843294$ & J259505960 \\
\hline Depth (m) & 251.7 & 254.7 & 327.6 & 291.0 & 379.2 & 347.3 & 328.9 & 595.5 \\
\hline $\mathrm{SiO}_{2}$ & 37.82 & 37.59 & 38.89 & 38.36 & 37.05 & 39.01 & 37.55 & 39.13 \\
\hline $\mathrm{Al}_{2} \mathrm{O}_{3}$ & 21.15 & 20.48 & 20.96 & 20.16 & 16.94 & 15.69 & 20.59 & 22.69 \\
\hline $\mathrm{FeO}$ & 29.02 & 33.39 & 29.60 & 26.21 & 14.32 & 15.59 & 16.99 & 27.00 \\
\hline $\mathrm{MnO}$ & 3.44 & 1.61 & 2.91 & 9.52 & 20.92 & 21.15 & 16.15 & 4.37 \\
\hline $\mathrm{MgO}$ & 6.48 & 5.09 & 5.71 & 2.60 & 0.51 & 1.09 & 2.50 & 5.57 \\
\hline $\mathrm{CaO}$ & 2.07 & 1.38 & 1.93 & 1.64 & 10.20 & 7.47 & 6.22 & 1.24 \\
\hline $\mathrm{Na}_{2} \mathrm{O}$ & bdl & bdl & bdl & 0.70 & bdl & bdl & bdl & bdl \\
\hline $\mathrm{K}_{2} \mathrm{O}$ & bdl & 0.46 & bdl & 0.81 & bdl & bdl & bdl & bdl \\
\hline TOTAL & 99.97 & 100.00 & 100.00 & 100.00 & 99.95 & 100.00 & 100.08 & 100.00 \\
\hline Oxygens & 12 & 12 & 12 & 12 & 12 & 12 & 12 & 12 \\
\hline $\mathrm{Si}$ & 2.984 & 3.006 & 3.057 & 3.085 & 3.057 & 3.198 & 3.009 & 3.043 \\
\hline $\mathrm{Al}$ & 1.967 & 1.931 & 1.943 & 1.912 & 1.648 & 1.517 & 1.944 & 2.080 \\
\hline $\mathrm{Fe}^{2+}$ & 1.915 & 2.234 & 1.946 & 1.763 & 0.988 & 1.069 & 1.138 & 1.756 \\
\hline $\mathrm{Mn}$ & 0.230 & 0.109 & 0.194 & 0.649 & 1.462 & 1.469 & 1.096 & 0.288 \\
\hline $\mathrm{Mg}$ & 0.762 & 0.606 & 0.668 & 0.312 & 0.062 & 0.134 & 0.298 & 0.646 \\
\hline $\mathrm{Ca}$ & 0.175 & 0.118 & 0.163 & 0.141 & 0.902 & 0.656 & 0.534 & 0.103 \\
\hline $\mathrm{Na}$ & $\mathrm{nc}$ & $\mathrm{nc}$ & $\mathrm{nc}$ & 0.109 & $\mathrm{nc}$ & $\mathrm{nc}$ & nc & nc \\
\hline $\mathrm{K}$ & $\mathrm{nc}$ & 0.047 & $\mathrm{nc}$ & 0.083 & $\mathrm{nc}$ & $\mathrm{nc}$ & $\mathrm{nc}$ & $\mathrm{nc}$ \\
\hline SUM & 8.033 & 8.052 & 7.971 & 8.055 & 8.119 & 8.043 & 8.019 & 7.916 \\
\hline$X_{M g}$ & 0.25 & 0.20 & 0.22 & 0.11 & 0.02 & 0.04 & 0.11 & 0.24 \\
\hline Alman & 62.1 & 72.8 & 65.5 & 61.5 & 28.9 & 32.1 & 37.1 & 62.9 \\
\hline Pyrop & 24.7 & 19.8 & 22.5 & 10.9 & 1.8 & 4.0 & 9.7 & 23.1 \\
\hline Gross & 5.7 & 3.9 & 5.5 & 4.9 & 26.4 & 19.7 & 17.4 & 3.7 \\
\hline Spess & 7.5 & 3.6 & 6.5 & 22.6 & 42.8 & 44.2 & 35.7 & 10.3 \\
\hline
\end{tabular}

in differentiated acid rocks and carbonatites. However, in the case of the Jõhvi rocks, especially MagQ, also magnetite is rich in manganese constituting in some magnetite gains more than $4000 \mathrm{ppm}$ (Table 6).

\section{DISCUSSION}

Historically, the term 'magnetite quartzites' has been extensively used for the magnetite-rich variety of Jõhvi gneisses. In the case where magnetite and quartz with a minor amount of other minerals (garnet, micas, feldspars) form micro-layered rock associations, this term is well characterizing the rock type. However, in a classical meaning quartzite is a non-foliated metamorphic rock which was originally pure quartz sandstone. It may contain magnetite, but usually not in economic quantities. The British Geological Survey defines quartzite as psammites containing more than $80 \%$ quartz (Robertson 1999), while the US Geological Survey describes it as a rock containing $>75 \%$ quartz (North American GeologicMap Data Model Science Language Technical Team 2004). The term 'quartzite' is also used for quartzcemented quartz arenites. In the case of Jõhvi rocks, the term 'magnetite quartzite' is somewhat misleading if applying to the whole section of iron-rich gneisses, since the magnetite-rich rocks are gneisses containing plagioclase (up to $35 \%$ ), other feldspars, pyroxenes (up to $20 \%$ ), garnet and sulphide ore minerals along with magnetite and hematite. However, there are beds from several tens of centimetres to several metres thick where quartz prevails in the mineral composition of rock and which are enriched in magnetite (small amount of other minerals). Those beds, restricted in size, can be named as magnetite quartzites proper, but in a large variety of magnetitebearing gneisses the content of quartz is less than $50 \%$ in 
Table 6. LA-ICP-MS analyses of magnetites from the Jõhvi magnetite quartzites. Altogether 38 analyses were performed on five magnetite grains (Mt1-Mt5) from the polished section of drill core J-1 (depth $312.1 \mathrm{~m}$ ). Average compositions of these grains are provided in the table

\begin{tabular}{lcrrrr}
\hline & Mt1 & Mt2 & Mt3 & Mt4 & Mt5 \\
\hline $\mathrm{Mg}$ & 138 & 383 & 358 & 210 & 219 \\
$\mathrm{Al}$ & 1672 & 2520 & 1341 & 1291 & 1605 \\
$\mathrm{Si}$ & 378 & 1198 & 965 & 564 & 401 \\
$\mathrm{Ca}$ & 120 & 138 & 120 & 120 & 112 \\
$\mathrm{Ti}$ & 2364 & 2256 & 2659 & 1783 & 1486 \\
$\mathrm{~V}$ & 162 & 255 & 185 & 197 & 179 \\
$\mathrm{Cr}$ & 172 & 191 & 143 & 130 & 121 \\
$\mathrm{Mn}$ & 1767 & 1739 & 2706 & 1728 & 1721 \\
$\mathrm{Ni}$ & 26 & 23 & 25 & 24 & 37 \\
$\mathrm{Cu}$ & 1.3 & 0.3 & 2.4 & 0.6 & 0.7 \\
$\mathrm{Zn}$ & 126 & 217 & 408 & 80 & 72 \\
\hline
\end{tabular}

volume. Therefore, in the future, after new drilling material becomes available, a more detailed study of the mineralogical and geochemical variation of the Jõhvi ore formation should be carried out in order to define rock varieties. It also needs to be noted that the boundary between the magnetite-rich varieties and the surrounding gneisses which may also contain some magnetite (and hematite) is gradual.

\section{A question of manganese and other base metals}

The new studies on major and trace element geochemistry revealed high manganese contents (1-6wt \%) in most of the MagQ samples and in rare occasions in the surrounding gneisses. Manganese-rich MagQ are also known in the Jägala rock complex of the Tallinn Zone (Luha 1946; Erisalu et al. 1969; Petersell 1976). In most cases, iron-mineralization spreads in garnet-cordierite, amphibole and pyroxene gneisses. Some amount of finegrained magnetite along with hematite, pyrrhotite and pyrite may occur in small-grained cordierite-sillimanitebiotite metasedimentary aluminium-rich gneisses throughout Estonia. In gabbroic intrusions, ilmenite-magnetite and magnetite-apatite mineralization has also been noted (Petersell et al. 1991).

Various hypotheses of ore genesis have been proposed for the Jõhvi MagQ. Linari (1940) suggests that the ore is skarn-like, while Vaganova \& Kadyrova (1948) propose metasomatic origin. Tikhomirov (1966) has described these rocks as alternating layers of skarn, cummingtonite, biotite-sillimanite and other hornfels that are cut by granite veins. However, the most widely recognized is the concept of metamorphic origin after the rocks of volcanogenic-sedimentary origin (Puura \& Kuuspalu 1966; Erisalu et al. 1969).

The type of iron-ore mineralization (e.g. deposit type) can be followed, for instance, by magnetite chemical composition. According to Dupuis \& Beaudoin (2011), magnetite trace element composition can be used for drawing petrogenetic discriminant diagrams that show trace element fingerprint of magnetite. Based on 111 samples, a plot for the characteristic zones of main iron deposit types has been constructed by Dupuis \& Beaudoin (2011). They recommended to use these diagrams together and in the suggested order in order to classify the deposit type.

$\mathrm{The} \mathrm{Si}+\mathrm{Mg}$ vs $\mathrm{Ni}+\mathrm{Cr}$ diagram (Fig. $8 \mathrm{~A}$ ) discards a $\mathrm{Ni}-\mathrm{Cu}$ type of deposit for the Jõhvi rocks as the analysed grains are not enriched in $\mathrm{Ni}$ or $\mathrm{Cr}$, unlike the magnetites in typical $\mathrm{Ni}-\mathrm{Cu}$ and $\mathrm{Cr}$ deposits (Table 6). The second diagram, $\mathrm{Cu} /(\mathrm{Si}+\mathrm{Ca})$ vs $\mathrm{Al} /(\mathrm{Zn}+\mathrm{Ca})$, differentiates volcanic massive sulphate (VMS) deposit type from the other types of deposits. The Jõhvi magnetites plot far away from the VMS zone (Fig. 8B). The third, Ti + V vs $\mathrm{Ni} /(\mathrm{Cr}+\mathrm{Mn})$ diagram shows clear clusters of various deposit types aside from the skarn type of deposit where magnetites have generally lower $\mathrm{Ti}+\mathrm{V}$ concentrations but variable $\mathrm{Ni} /(\mathrm{Cr}+\mathrm{Mn})$ ratios (Fig. $8 \mathrm{C})$. The analysed Jõhvi magnetites form a group outside the plotted types of deposits, suggesting that Jõhvi magnetites do not represent clearly any of the compared deposit types (Fig. 8C). As the skarn field is not distinguished by the lower $\mathrm{Ni} /(\mathrm{Cr}+\mathrm{Mn})$ border in the diagram by Dupuis \& Beaudoin (2011), it may be plausible that the Jõhvi magnetites bear similarities with the skarn type of deposits, albeit having lower nickel and higher manganese concentrations. The analysed magnetites also have a high $\mathrm{Ti}+\mathrm{V}$ concentration which is not common for skarn deposits (Dupuis \& Beaudoin 2011) and therefore plot on the $\mathrm{Ti}+\mathrm{V}$ vs $\mathrm{Ca}+\mathrm{Al}+\mathrm{Mn}$ diagram in the porphyry-type field, close to the skarn and iron oxide-copper-gold type of ores (Fig. 8D).

The magnetite grains analysed from drill core J-1 show that classifying Jõhvi magnetites into a certain deposit type is not unambiguous. On the $\mathrm{Ti}+\mathrm{V}$ vs $\mathrm{Ni} /(\mathrm{Cr}+\mathrm{Mn})$ diagram, the analysed samples plot quite away from the other types possibly because of the relatively high content of manganese in the magnetite. Duo to a small number of analyses from only a single drill core, the question of the origin of the Jõhvi iron-ore remains open, as well as the source for the elevated manganese concentrations in the rock and magnetite.

Two minerals carrying manganese can be envisaged garnets and $\mathrm{Mn}$-ilmenites. In some parts, Mn-rich pyroxenes can probably also contribute to the overall manganese budget of the ore formation. Garnet is 

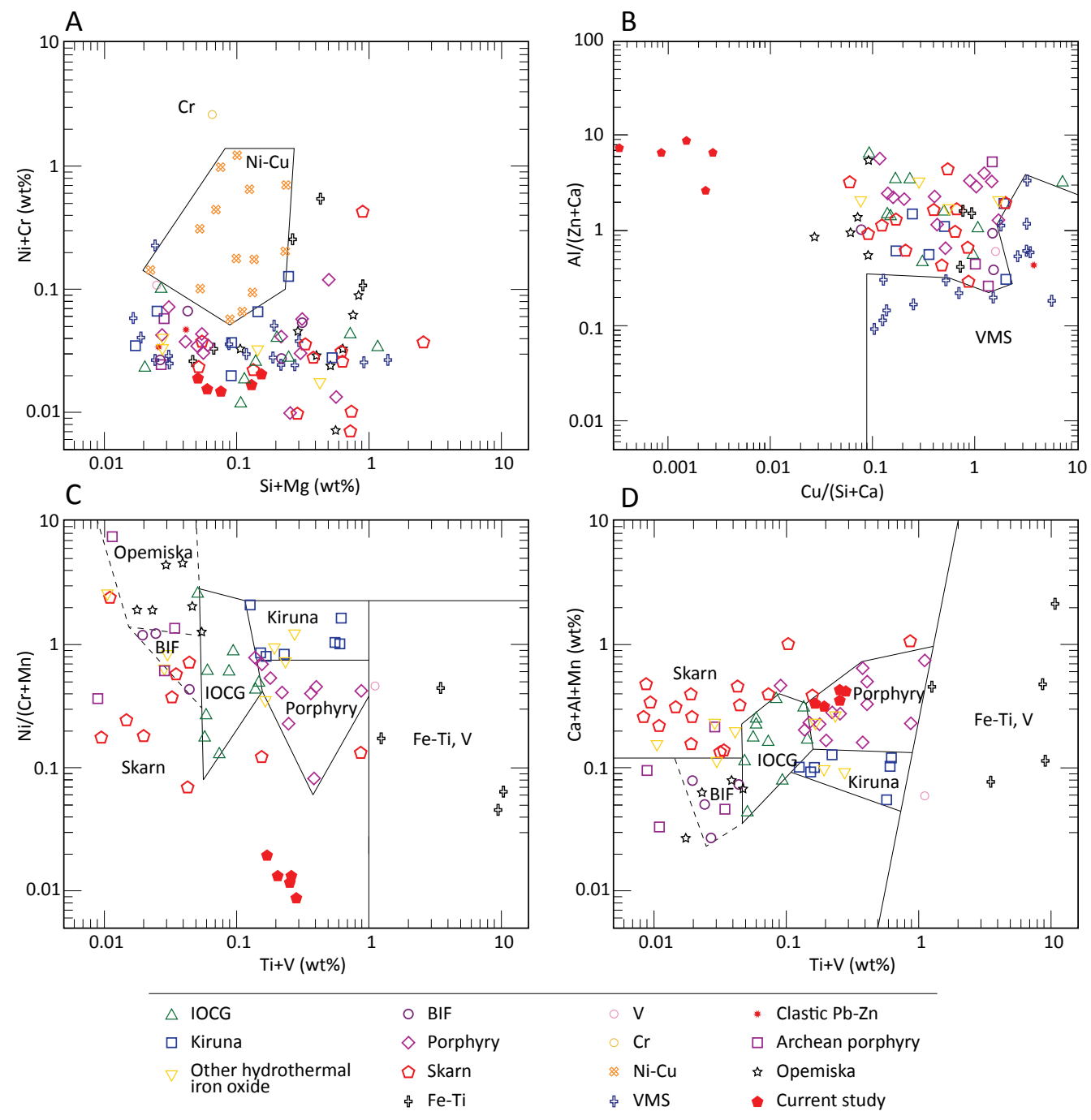

Fig. 8. Magnetite chemical composition on discriminant diagrams: $\mathrm{Si}+\mathrm{Mg}$ vs $\mathrm{Ni}+\mathrm{Cr}(\mathbf{A}), \mathrm{Cu} /(\mathrm{Si}+\mathrm{Ca})$ vs $\mathrm{Al} /(\mathrm{Zn}+\mathrm{Ca})(\mathbf{B}), \mathrm{Ti}+\mathrm{V}$ vs Ni/(Cr $+\mathrm{Mn})(\mathbf{C})$ and $\mathrm{Ti}+\mathrm{V}$ vs $\mathrm{Ca}+\mathrm{Al}+\mathrm{Mn}(\mathbf{D})$. Average compositions of the analyses of the five Jõhvi magnetite grains are plotted together with the initial discriminant data by Dupuis \& Beaudoin (2011). The results are compared with magnetite trace element composition data from deposit types of iron oxide copper gold (IOCG), Kiruna, hydrothermal iron oxide, banded iron formation (BIF), porphyry, skarn, iron-titanium, vanadium, chromium, nickel-copper, volcanic massive sulphide (VMS), clastic leadzinc, Archean porphyry and Opemiska.

abundant in the Jõhvi gneisses, however, its overall content is neither high nor consistent with the location of Mn-rich MagQ (Fig. 4). Ilmenite may have 5-35 wt \% $\mathrm{Mn}$, but it is not widely spread in the rock and cannot account for high whole-rock manganese oxide contents $(1-6 \mathrm{wt} \%)$. Still, the actual protolith of the gneisses and the source of mineralization of the iron formation could only be hypothesized as the available rock material was too limited. The geological setting, banded texture of proper iron-rich MagQ and abundance of Al-rich garnets support the volcanogenic-sedimentary origin. Therefore, the initial enrichment of iron could be explained by iron deposition similar to the genesis of the Algoma-type banded iron formations. However, metasomatic processes are responsible for an additional concentration of some metals, i.e. iron and manganese. In this respect, the origin of the Jõhvi iron formation may well be a complex process. Hopefully, the future studies on the new rock material from the Jõhvi area will help to answer these questions.

The modern geological-geochemical correlation hints at geological similarities between the Bergslagen area in Sweden and the Jõhvi area (Voolma et al. 2010; Bogdanova et al. 2015, fig. 9; Nirgi \& Soesoo 2019). By 
far the most common type of metallic mineral deposits in Bergslagen consists of iron oxide with variable amounts of $\mathrm{Mn}$ in associated skarn and metacarbonate rocks (Allen et al. 2003, 2008; Voolma et al. 2010).

More than 2000 deposits are known in the Bergslagen area, most of which are small and, since the middle of the 19 th century, without any economic significance. The economically important iron oxide deposits in Bergslagen may be subdivided into the following categories: (1) iron oxide deposits in Mn-poor and Mn-rich skarn and carbonate rocks, (2) quartz-rich iron oxide deposits including banded iron formations and (3) apatite-bearing iron oxide deposits. In addition, iron oxide deposits associated with high contents of sulphides of base metals are present. The above-mentioned iron oxide types may be considered as end members, and characteristics corresponding to more than one type are locally found in different places of, or along strike, in the same deposit. For example, some iron oxide skarn deposits in Bergslagen appear to grade into quartz-rich iron deposits. Most of the skarns associated with Fe oxide ores, base metal sulphide ores and those scattered through the volcanic succession, are currently interpreted as a result of regional metamorphism of interbedded sedimentary and volcanic rocks and/or hydrothermal sediments, or of regional metamorphism of earlier hydrothermally altered rocks (Allen et al. 2003, 2008). Most of the skarns are not spatially associated with particular intrusions. This may or may not be the case for the Jõhvi iron ore and associated metals as well. New geological material and geochemical studies are needed to prove or disprove this possible geological similarity.

\section{Evaluation of metamorphic $P-T$ conditions}

The rocks of the Jõhvi Zone are usually regarded as rocks of granulite metamorphic facies (Puura et al. 1983). However, very little research has been done on the geothermobarometry of these rocks. To understand the geological history, and also ore genesis, some knowledge about the metamorphic history is necessary. Therefore, an attempt was made to get some indication for temperature and pressure estimates on the Jõhvi MagQ and surrounding gneisses.

In order to acquire rock formation temperature conditions, the major element composition was measured in garnet and biotite. Metamorphism temperatures were calculated using the following calibration methods: Thompson (1976), Holdaway \& Lee (1977), Perchuk \& Lavrent'eva (1983), Dasgupta et al. (1991), Bhattacharya et al. (1992) (for results refer to Table 7). As the biotite grains in analysed samples were chemically similar (standard deviation of $\mathrm{Mg}$ and $\mathrm{Fe}$ concentrations below 0.06), the average values of $\mathrm{Mg}$ and $\mathrm{Fe}$ concentrations of biotite were used. The obtained results (Table 7) show that according to the $\mathrm{Fe} / \mathrm{Mg}$ ratio of garnets and biotite, the metamorphism temperatures that reflect the chemical variance of garnets form three recognizable clusters. The majority of calculated temperatures were between 650 and $750{ }^{\circ} \mathrm{C}$, which is also comparable with previous studies that suggest the temperature values of $650 \pm 50{ }^{\circ} \mathrm{C}$ (Voolma et al. 2010).

There are nearly 30 versions of the garnet-biotite thermometers at present. Among these the Holdaway (2000) version yields the smallest absolute error $\left( \pm 25^{\circ} \mathrm{C}\right)$ in reproducing the experimental temperatures of Ferry \& Spear (1978) and Perchuk \& Lavrent'eva (1983), in the wide temperature range of $550-950{ }^{\circ} \mathrm{C}$ (Wu et al. 2004; Table 7). Six thin sections from two drill cores (F-1 and F-12) were analysed. In sample F12910 the garnet-biotite temperature is $649^{\circ} \mathrm{C}$ according to the Holdaway (2000) thermometer. In sample F122517 seven garnet-biotite pairs were analysed. Temperature ranges from 658 to $755^{\circ} \mathrm{C}$, with an average of $708^{\circ} \mathrm{C}$ according to Holdaway (2000). In sample F122547 the average temperature was $647{ }^{\circ} \mathrm{C}$ in three garnet-biotite pairs. The lowest temperature was $629^{\circ} \mathrm{C}$ and the highest was $674{ }^{\circ} \mathrm{C}$. The garnet-biotite pair in sample F123276 gave the temperature of $669{ }^{\circ} \mathrm{C}$. In sample F13792 five garnetclinopyroxene pairs were analysed. According to the Nakamura (2009) geothermometer, the calculated temperature was $605-629{ }^{\circ} \mathrm{C}$, with a mean value of $615^{\circ} \mathrm{C}$. In sample F13473 garnet-clinopyroxene pairs gave two different results. The manganese-rich pyroxene (johannsenite) temperature was 942 and $971{ }^{\circ} \mathrm{C}$ according to the Nakamura (2009) geothermometer and manganesepoor pyroxene gave lower temperatures around $630{ }^{\circ} \mathrm{C}$. The large difference in temperatures may infer towards prolonged metasomatic processes during which some pyroxenes may have been re-equilibrated (showing the lower temperature).

Alumosilicate minerals are not always present. In this case the widely used garnet-aluminosilicate-plagioclasequartz barometer cannot be applied. Wu et al. (2004) calibrated the garnet-biotite-plagioclase-quartz barometer, so that it may be applied to metapelites, especially when aluminosilicate is absent. Metamorphic pressures for the studied rocks were calculated by the garnet-biotiteplagioclase-quartz (Wu et al. 2004) geobarometer. The calculated pressure was $4.3 \mathrm{kbar}$ in sample F12910, $4.9 \mathrm{kbar}$ in sample F122517, 2.9 kbar in sample F122547 and 5.6 kbar in sample F123276.

The metamorphic temperature was varying between 570 and $670{ }^{\circ} \mathrm{C}$ in the samples from drill cores $\mathrm{J}-1$ and $\mathrm{J}-2$, which is similar to the results of an earlier study by Voolma et al. (2010) giving an average of $650 \pm 50{ }^{\circ} \mathrm{C}$. It is noted that sample J132843294 gives systematically lower temperatures - between $508{ }^{\circ} \mathrm{C}$ (calculated after 


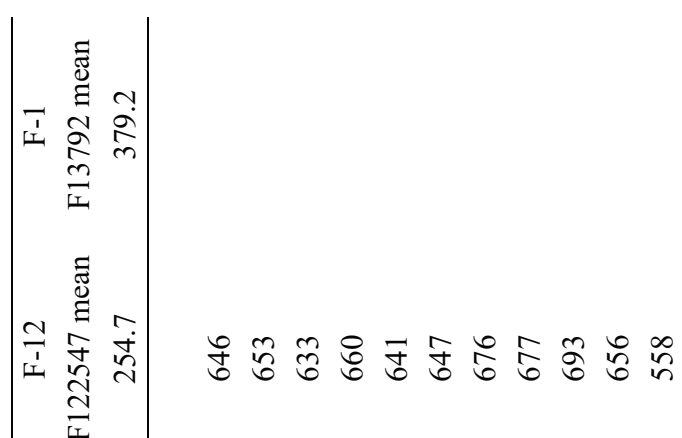

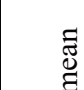

$\because \stackrel{7}{=}$

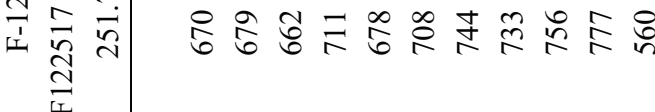

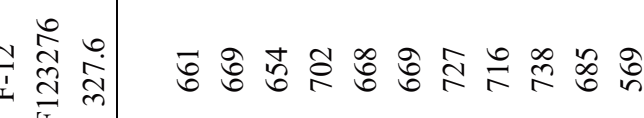

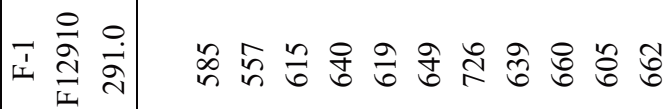

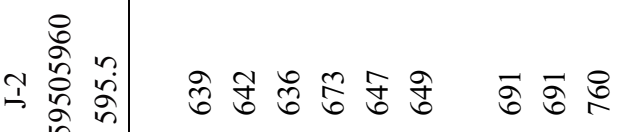

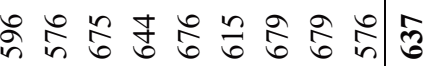


Ferry \& Spear 1978) and $717^{\circ} \mathrm{C}$ (after Dasgupta et al. 1991); still, the majority of calculated temperatures are between 530 to $570{ }^{\circ} \mathrm{C}$. However, two different sections of sample J259505960 (drill core J-2) gave a much smaller spread of calculated temperatures with an average of $645^{\circ} \mathrm{C}$ (Table 7). The preliminary conclusion is that drill core $\mathrm{J}-1$ shows a lower metamorphic temperature than core J-2. However, due to the small number of analyses, this difference cannot be confirmed yet. Having in mind that the entire Jõhvi ore complex may be a result of repeated metasomatic events, for example throughout the metasomatic processes, there is likely no simple way for estimating $P-T$ conditions. Instead, the surrounding rocks, which have not gone through metasomatic processes, should be targeted for pressure and temperature estimation purposes in the future.

\section{CONCLUSIONS}

The Jõhvi magnetite quartzites occur as subvertical beds with complicated structural elements in garnet-cordierite and pyroxene gneisses. Drill core study shows that the complex of magnetite-rich rocks may be up to $100 \mathrm{~m}$ thick. The studied samples can be divided into three major rock groups: (1) gneisses and iron-rich gneisses, (2) magnetite quartzites and (3) granitoids. Magnetite quartzites provide a wide range of major element composition while $\mathrm{SiO}_{2}$ ranges between 40.3 and $60.1 \mathrm{wt} \%$, $\mathrm{Al}_{2} \mathrm{O}_{3}$ between 1.7 and $19.7 \mathrm{wt} \%$ and $\mathrm{Fe}_{2} \mathrm{O}_{3}$ between 15 and $45.2 \mathrm{wt} \%$. The present study revealed unusually high manganese contents (1-6 wt\%). The majority of the magnetite quartzites follow a similar REE pattern to the surrounding gneisses. Granitoids form two entirely different patterns of REE.

Magnetite occurs as anhedral grains elongated along rock fabric, as rounded inclusions in other minerals or as tiny platelets along grain edges and along cleavage planes of amphibole and biotite. Sulphides are present as pyrite, pyrrhotite and other minor sulphide minerals (chalcopyrite, galena and sphalerite).

The calculated metamorphic temperatures (garnetbiotite geothermometer) fall between 650 and $750{ }^{\circ} \mathrm{C}$. The garnet-biotite-plagioclase-quartz geobarometer yielded the pressure range of 2.9 to $4.9 \mathrm{kbar}$. However, having in mind that the entire Jõhvi ore complex may be a result of repeated metasomatic events, there is likely no simple way for estimating $P-T$ conditions.

The magnetite grains analysed from drill core J-1 show that classifying Jõhvi magnetites into a certain deposit type is not unambiguous. The modern geologicalgeochemical correlation hints at geological similarities between the Bergslagen area in Sweden and the Jõhvi area.
Acknowledgements. The funding from the RITA programme by the European Regional Development Fund, sub-programme 'Metallogenesis of the Jõhvi area' is acknowledged. This research was partly funded by the Estonian Research Council grant RESTA20 to A. S. We thank the referees Gediminas Motuza and Juho Kirs for insightful reviews and Kalle Kirsimäe for valuable comments and suggestions which improved an earlier version of the manuscript. The publication costs of this article were partially covered by the Estonian Academy of Sciences.

\section{Supplementary online data}

The supplementary data table containing the results of chemical analysis of whole-rock samples from the Jõhvi magnetic anomaly is available online at https://doi.org/10.23679/506.

\section{REFERENCES}

Allen, R., Stuart, B., Ripa, M. \& Jonsson, R. 2003. Regional Stratigraphy, Basin Evolution, and the Setting of Stratabound $\mathrm{Zn}-\mathrm{Pb}-\mathrm{Cu}-\mathrm{Ag}-\mathrm{Au}$ Deposits in Bergslagen, Sweden. Final report for SGU-FoU project 03-1203/99.

Allen, R., Ripa, M. \& Jansson, N. 2008. Palaeoproterozoic Volcanic-and Limestone-Hosted $\mathrm{Zn}-\mathrm{Pb}$ - $\mathrm{Ag}$-(Cu-Au) Massive Sulphide Deposits and Fe Oxide Deposits in Bergslagen, Sweden. 33 IGC excursion No. 12, August 14-20.

Anders, E. \& Grevesse, N. 1989. The abundances of the elements: meteoritic and solar. Geochimica et Cosmochimica Acta, 53, 197-214.

Berman, R. G., Aranovich, L. Y. \& Pattison, D. R. M. 1995. Reassessment of the garnet-clinopyroxene $\mathrm{Fe}-\mathrm{Mg}$ exchange thermometer: II. Thermodynamic analysis. Contributions to Mineralogy and Petrology, 119, 30-42.

Bhattacharya, A., Mohanty, L., Maji, A., Sen, S. K. \& Raith, M. 1992. Non-ideal mixing in the phlogopite-annite binary: constraints from experimental data on $\mathrm{Mg}-\mathrm{Fe}$ partitioning and reformulation of the biotite-garnet geothermometer. Contributions to Mineralogy and Petrology, 111, 87-93.

Bogdanova, S., Gorbachev, R., Skridlaite, G., Soesoo, A., Taran, L. \& Kurlovich, D. 2015. Trans-Baltic Palaeoproterozoic correlations towards the reconstruction of supercontinent Columbia/Nuna. Precambrian Research, 259, 5-33.

Craig, J. R. \& Vaughan, D. J. 1994. Ore Microscopy and Ore Petrography, 2nd ed. John Wiley \& Sons, Inc., New York, $434 \mathrm{pp}$.

Dasgupta, S., Sengupta, P. \& Guha, D. 1991. A refined garnet biotite $\mathrm{Fe}-\mathrm{Mg}$ exchange geothermometer and its application in amphibolites and granulites. Contributions to Mineralogy and Petrology, 109, 130-137.

Deer, W. A., Howie, R. A. \& Zussman, J. 1992. An Introduction to the Rock Forming Minerals, 2nd ed. Pearson Ed. Ltd., Essex, $696 \mathrm{pp}$.

Dupuis, C. \& Beaudoin, G. 2011. Discriminant diagrams for iron oxide trace element fingerprinting of mineral deposit types. Mineralium Deposita, 46, 319-335. 
Ellis, D. J. \& Green, D. H. 1979. An experimental study of the effect of $\mathrm{Ca}$ upon garnet-clinopyroxene $\mathrm{Fe}-\mathrm{Mg}$ exchange equilibria. Contributions to Mineralogy and Petrology, 71, $13-22$.

Erisalu, E., Arvisto, E., Norman, A., Danchenko, V., Koppelmaa, H., Niin, M. \& Kivisilla, J. 1969. Otchet po izucheniyu kristallicheskogo fundamenta Jykhviskoj magnitnoj anomalii i ee okrestnostej [Report of the Basement Studies on Jõhvi Magnetic Anomaly and Nearby]. Geological Survey of Estonia, Tallinn, EGF 3032, 257 pp [in Russian].

Ferry, J. M. \& Spear, F. S. 1978. Experimental calibration of the partitioning of $\mathrm{Fe}$ and $\mathrm{Mg}$ between biotite and garnet. Contributions to Mineralogy and Petrology, 66, 113-117.

Ganguly, J. 1979. Garnet and clinopyroxene solid solutions, and geothermometry based on $\mathrm{Fe}-\mathrm{Mg}$ distribution coefficient. Geochimica et Cosmochimica Acta, 43, 101-129.

Ganguly, J. \& Saxena, S. K. 1984. Mixing properties of aluminosilicate garnets: constraints from natural and experimental data, and applications to geothermo-barometry. American Mineralogist, 69, 88-97.

Ganguly, J., Cheng, W. \& Tirone, M. 1996. Thermodynamics of aluminosilicate garnet solid solution: new experimental data, an optimized model, and thermometric applications. Contributions to Mineralogy and Petrology, 126, 131-151.

Hall, A. J. 1986. Pyrite-pyrrhotine redox reactions in nature. Mineralogical Magazine, 50, 223-229.

Hodges, K. V. \& Spear, F. S. 1982. Geothermometry, geobarometry and the $\mathrm{Al}_{2} \mathrm{SiO}_{5}$ triple point at Mt. Moosilauke, New Hampshire. American Mineralogist, 67, 1118-1134.

Holdaway, M. J. 2000. Application of new experimental and garnet Margules data to the garnet-biotite geothermometer. American Mineralogist, 85, 881-892.

Holdaway, M. J. \& Lee, S. M. 1977. Fe-Mg cordierite stability in high-grade pelitic rocks based on experimental, theoretical and natural observation. Contributions to Mineralogy and Petrology, 63, 175-198.

Lagoeiro, L. E. 2004. Transformation of magnetite to hematite and its influence on the dissolution of iron oxide minerals. Journal of Metamorphic Petrology, 16, 415-423.

Linari, A. A. 1940. Aruanne sügavpuurimistest Jõhvi lähedal [Report on diamond drilling near Jõhvi]. Tallinna Tehnikaülikooli Toimetused, Ser. A, 15, 1-27 [in Estonian, with English summary].

Luha, A. 1946. Eesti NSV maavarad. Rakendusgeoloogiline kokkuvõtlik ülevaade [Earth Resources in the ÉSSR. Concluding Overview of Geological Appliances]. Teaduslik Kirjandus, Tartu, 176 pp. [in Estonian].

Nakamura, D. 2009. A new formulation of garnet-clinopyroxene geothermometer based on accumulation and statistical analysis of a large experimental data set. Journal of Metamorphic Geology, 27, 495-508.

Nirgi, S. \& Soesoo, A. 2019. Precambrian iron-sulphide mineralization of NE Estonia. In 21st EGU General Assembly, EGU2019, 7-12 April, 2019 Vienna, Austria. Geophysical Research Abstracts, 21, id.12651.

North American Geologic-Map Data Model Science Language Technical Team. 2004. Report on progress to develop a North American science-language standard for digital geologic-map databases; Appendix B - Classification of metamorphic and other composite-genesis rocks, including hydrothermally altered, impact-metamorphic, mylonitic, and cataclastic rocks, Version 1.0 (12/18/2004). In Digital Mapping Techniques '04 - Workshop Proceedings: U.S. Geological Survey Open-File Report 2004-1451 (Soller, D. R., ed.), $56 \mathrm{pp}$.

Perchuk, L. L. \& Lavrent'eva, I. V. 1983. Experimental investigation of exchange equilibria in the system cordierite-garnet-biotite. In Kinetics and Equilibrium in Mineral Reactions (Saxena, S. K., ed.), pp. 199-239. Springer, Berlin, Heidelberg, New York.

Petersell, V. 1976. Osnovnye cherty geologii i rudonosnosti kristallicheskogo fundamenta yuzhnogo sklona Baltijskogo shchita [Geological and Metallogeny Features of the Crystalline Basement of the Southern Slope of the Baltic Shield]. ENSV Teaduste Akadeemia Geoloogia Instituut, Tallinn, 28 pp. [in Russian].

Petersell, V., Kivisilla, J., Pukkonen, E., Põldvere, A. \& Täht, K. 1991. Otchet ob otsenke rudoproyavlenij $i$ tochek mineralizatsii v osadochnom chekhle i kristallicheskom fundamente Éstonii [Evaluation of Ore Occurrences and Mineralization Points in Estonian Bedrock and Crystalline Basement]. Geological Survey of Estonia, Tallinn, EGF 4523, 284 pp. [in Russian].

Plado, J., Kiik, K., Jokinen, J. \& Soesoo, A. 2020. Magnetic field of the Jõhvi iron ore anomaly, northeastern Estonia, controlled by subvertical remanent magnetization. Estonian Journal of Earth Sciences, 69, 189-199.

Powell, R. 1985. Regression diagnostics and robust regression in geothermometer/geobarometer calibration: the garnetclinopyroxene geothermometer revisited. Journal of Metamorphic Geology, 3, 231-243.

Puura, V. \& Kuuspalu, T. 1966. Metallogenicheskaya karta Éstonskoj SSR m-ba 1:500000. Otchet III. Rudoproyavleniya $v$ kristallicheskom fundamente uchastkov Jyhvi i Ul'yaste [Map of Metallogeny of the Estonian S.S.R. in a Scale of 1:500 000. Volume III. Ore Occurrences in the Crystalline Basement of the Jôhvi and Uljaste Areas]. Geological Survey of Estonia, Tallinn, EGF 2801, 267 pp. [in Russian].

Puura, V., Vaher, R., Klein, V., Koppelmaa, H., Niin, M., Vanamb, V. \& Kirs, J. 1983. Kristallicheskij fundament Éstonii [The Crystalline Basement of Estonian Territory]. Nauka, Moscow, 208 pp. [in Russian, with extended English summary].

Puura, V., Klein, V., Kikas, R., Konsa, M., Kuldkepp, R. \& Soesoo, A. 2004. Svecofennian metamorphic zones in the basement of Estonia. Proceedings of the Estonian Academy of Sciences, Geology, 53, 190-209.

Ravna, E. J. K. 2000. The garnet-clinopyroxene Fe2+-Mg geothermometer: An updated calibration. Journal of Metamorphic Geology, 18, 211-219.

Robertson, S. 1999. BGS Rock Classification Scheme: Classification of Metamorphic Rocks. British Geological Survey Research Report, Volume 2, RR 99-02, 26 pp.

Slotznick, S. P., Eiler, J. M. \& Fischer, W. W. 2018. The effects of metamorphism on iron mineralogy and the iron speciation redox proxy. Geochimica et Cosmochimica Acta, 224, 96-115. 
Soesoo, A., Puura, V., Kirs, J., Petersell, V., Niin, M. \& All, T. 2004. Outlines of the Precambrian basement of Estonia. Proceedings of the Estonian Academy of Sciences, Geology, 53, 149-164.

Soesoo, A., Košler, J. \& Kuldkepp, R. 2006. Age and geochemical constraints for partial melting of granulites in Estonia. Mineralogy and Petrology, 86, 277-300.

Soesoo, A., Nirgi, S. \& Plado, J. 2020. The evolution of the Estonian Precambrian basement: geological, geophysical and geochronological constraints. Transactions of the Karelian Research Centre of the Russian Academy of Sciences, 2, 18-33.

Thompson, A. B. 1976. Mineral reactions in pelitic rocks, II: Calculation of some P-T-X $(\mathrm{Fe}-\mathrm{Mg})$ phase relations. American Journal of Science, 276, 425-454.

Tikhomirov, S. N. 1966. Geologiya kristallicheskogo fundamenta $v$ Leningradskoj oblasti i Pribaltiki [Geology of the Crystalline Basement in the Leningrad Region and Baltics]. VSEGEI, Leningrad, 24 pp. [in Russian].
Vaganova, Z. \& Kadyrova, M. 1948. Dokembrijskie kristallicheskie porody i zhelezistye kvartsity Ést. SSR [Precambrian Crystalline Rocks and Iron-Rich Quartzites of the Estonian S.S.R.]. Ministry of Geology of the S.S.S.R., Leningrad, 228 pp. [in Russian].

Voolma, M., Soesoo, A. \& Hade, S. 2010. Geochemistry and $\mathrm{P}-\mathrm{T}$ conditions of magnetite quartzites from Jõhvi Zone, NE Estonia. In Proceedings of the 5th Annual Meeting of Nordic Mineralogical Network, Tallinn, 14th-18th June 2010 (Tuisku, P. \& Nemliher, J., eds), Res Terrae: Publications of the Department of Geosciences, University of Oulu, A31, 42-46.

Williams, M. L. \& Grambling, J. A. 1990. Manganese, ferric iron, and the equilibrium between garnet and biotite. American Mineralogist, 75, 886-908.

Wu, C., Zhang, J. \& Ren, L. 2004. Empirical garnet-biotiteplagioclase-quartz (GBPQ) geobarometry in medium- to high-grade metapelites. Journal of Petrology, 45, 19071921.

\section{Jõhvi magnetiidirikaste gneisside geokeemia ja tekke rõhu- ning temperatuuritingimused}

\section{Alvar Soesoo, Siim Nirgi, Kristjan Urtson ja Margus Voolma}

Jõhvi magnetiiti sisaldavad gneissid (sh magnetiit-kvartsiidid) moodustavad kuni 100 m paksusi kivimikehi. Rauasisaldus neis kivimites on väga varieeruv ja ulatub kuni 45 massiprotsendini. Kohati sisaldab kivim suures koguses ka mangaani, mangaanoksiidi sisaldus võib ulatuda 6 kaaluprotsendini. Kivim sisaldab ka sulfiidseid mineraale, nagu püriit, pürrotiit, kalkopüriit, galeniit ja sfaleriit. Rauarikas kivimikeha on kohati lõigatud vähemasti kahe keemiliselt erineva graniiditüübi intrusioonidega. Mineraalide keemilise koostise alusel on arvutatud kivimi tekke temperatuur ja rõhk. Granaadi-biotiidi geotermomeeter annab temperatuurivahemiku 650 kuni 750 kraadi. Granaadi-biotiidi-plagioklassikvartsi geobaromeeter näitab laia rõhuvahemikku: 2,9 kuni 4,9 kbar. Arvestades, et Jõhvi rauarikkad gneissid on ilmselt moondunud mitme metasomaatilise tsükli käigus, ei pruugi praegused temperatuuri- ja rõhuväärtused iseloomustada kivimikeha algtekkelisi väärtusi. Jõhvi kivimikompleksid on sarnased Rootsi Bergslageni kompleksiga. 